\title{
Article \\ Physiological and Biochemical Response to Fusarium culmorum Infection in Three Durum Wheat Genotypes at Seedling and Full Anthesis Stage
}

\author{
Jakub Pastuszak ${ }^{1, *(\mathbb{D}}$, Anna Szczerba ${ }^{1}$, Michał Dziurka ${ }^{2}\left(\mathbb{D}\right.$, Marta Hornyák ${ }^{1,3}$, Przemysław Kopeć ${ }^{2}{ }^{(}$, \\ Marek Szklarczyk ${ }^{4}$ and Agnieszka Płażek ${ }^{1}$ D \\ 1 Department of Plant Breeding, Physiology and Seed Science, University of Agriculture, Podłużna 3, \\ 30-239 Kraków, Poland; anna.szczerba21@gmail.com (A.S.); marta.hornyak@botany.pl (M.H.); \\ rrplazek@cyf-kr.edu.pl (A.P.) \\ 2 Franciszek Górski Institute of Plant Physiology, Polish Academy of Sciences, Niezapominajek 21, \\ 30-239 Kraków, Poland; m.dziurka@ifr-pan.edu.pl (M.D.); p.kopec@ifr-pan.edu.pl (P.K.) \\ 3 Polish Academy of Sciences, W. Szafer Institute of Botany, Lubicz 46, 31-512 Kraków, Poland \\ 4 Faculty of Biotechnology and Horticulture, University of Agriculture, 29 Listopada 54, \\ 31-425 Kraków, Poland; marek.szklarczyk@urk.edu.pl \\ * Correspondence: jakub.pastuszak@urk.edu.pl
}

\section{check for}

updates

Citation: Pastuszak, J.; Szczerba, A.; Dziurka, M.; Hornyák, M.; Kopeć, P.; Szklarczyk, M.; Płażek, A.

Physiological and Biochemical Response to Fusarium culmorum Infection in Three Durum Wheat Genotypes at Seedling and Full Anthesis Stage. Int. J. Mol. Sci. 2021 22, 7433. https://doi.org/10.3390/ ijms22147433

Academic Editor: Marcello Iriti

Received: 18 June 2021

Accepted: 8 July 2021

Published: 11 July 2021

Publisher's Note: MDPI stays neutral with regard to jurisdictional claims in published maps and institutional affiliations.

Copyright: (c) 2021 by the authors. Licensee MDPI, Basel, Switzerland. This article is an open access article distributed under the terms and conditions of the Creative Commons Attribution (CC BY) license (https:// creativecommons.org/licenses/by/ 4.0/)
Abstract: Fusarium culmorum is a worldwide, soil-borne plant pathogen. It causes diseases of cereals, reduces their yield, and fills the grain with toxins. The main direction of modern breeding is to select wheat genotypes the most resistant to Fusarium diseases. This study uses seedlings and plants at the anthesis stage to analyze total soluble carbohydrates, total and cell-wall bound phenolics, chlorophyll content, antioxidant activity, hydrogen peroxide content, mycotoxin accumulation, visual symptoms of the disease, and Fusarium head blight index (FHBi). These results determine the resistance of three durum wheat accessions. We identify physiological or biochemical markers of durum wheat resistance to F. culmorum. Our results confirm correlations between FHBi and mycotoxin accumulation in the grain, which results in grain yield decrease. The degree of spike infection (FHBi) may indicate accumulation mainly of deoxynivalenol and nivalenol in the grain. High catalase activity in the infected leaves could be considered a biochemical marker of durum sensitivity to this fungus. These findings allowed us to formulate a strategy for rapid evaluation of the disease severity and the selection of plants with higher level, or resistance to F. culmorum infection.

Keywords: antioxidant enzymes; deoxynivalenol; Fusarium culmorum; mycotoxins; nivalenol; Triticum durum

\section{Introduction}

Fungi of Fusarium species are responsible for numerous diseases in wheat and other small grain cereals cultivated worldwide. Fusarium culmorum (Wm.G. Sm.) Sacc. is a threat to plants at every stage of their development. The infection evoked by this pathogen is a serious problem in cereal agriculture. The most common symptoms of Fusarium wilt in wheat include Fusarium seedling blight (FSB), root rot, and Fusarium head blight (FHB). These symptoms have especially disadvantageous effects on plant growth, development, grain yield, and its quality [1-3]. The yield reduction is an outcome of damaged kernels which appear discolored and shriveled. Fusarium culmorum belongs to the fungi producing numerous dangerous toxins, such as deoxynivalenol (DON) (Figure 1A), nivalenol (NIV) (Figure 1B), T-2 toxin (Figure 1C), and zearalenone (ZEN) (Figure 1D). These mycotoxins represent the trichothecenes family, i.e., epoxy-sesquiterpenoid metabolites responsible for pathogenic virulence and protein synthesis $[4,5]$. Food products and fodder contaminated with secondary metabolites of F. culmorum may evoke severe and chronic harm to human and domestic animal health [6-8]. In the food industry, grain infected with Fusarium, in which the level of mycotoxins exceeds the permissible EU standards, must be discarded. 
The maximum limit of toxins are: $750 \mu \mathrm{g} \cdot \mathrm{kg}^{-1} \mathrm{DON}$ and $75 \mu \mathrm{g} \cdot \mathrm{kg}^{-1} \mathrm{ZEN}$ in flour, and $500 \mu \mathrm{g} \cdot \mathrm{kg}^{-1} \mathrm{DON}$ and $50 \mu \mathrm{g} \cdot \mathrm{kg}^{-1} \mathrm{ZEN}$ in bread. The toxin levels are also established for feed production at $900 \mu \mathrm{g} \cdot \mathrm{kg}^{-1}$ DON for pigs and $100 \mu \mathrm{g} \cdot \mathrm{kg}^{-1} \mathrm{ZEN}$ for piglets $[9,10]$.

A

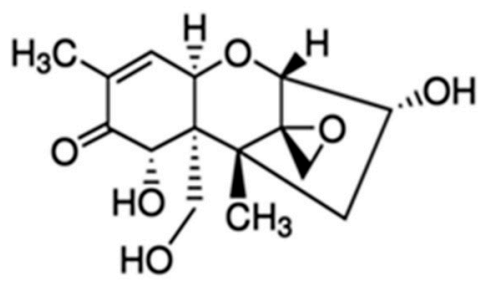

Deoxynivalenol (DON)

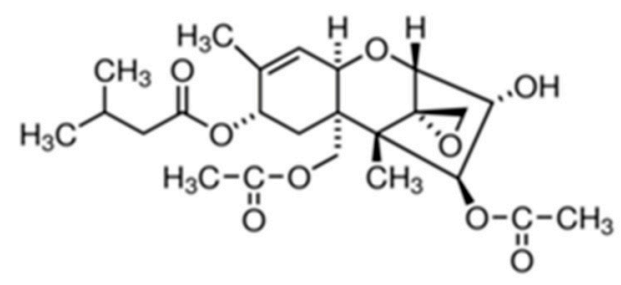

T-2 toxin

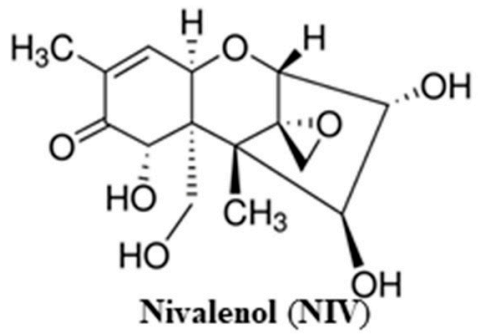

$\mathrm{C}$<smiles>CC(O)CCCC(O)CCC/C=C/c1cc(O)cc(O)c1C(=O)O</smiles>

Zearalenone (ZEN)
B

D

Figure 1. Secondary metabolites (mycotoxins) produced by Fusarium culmorum: (A) deoxynivalenol (DON), (B) nivalenol (NIV), (C) T-2 toxin, (D) zearalenone (ZEN).Source: Sigma-Aldrich.

Resistance to Fusarium head blight is a complex, quantitative trait. Several types (mechanisms) of resistance were identified, and they were described as: Type I-resistance to an initial infection; type II-resistance to the pathogen spread within the host; type III—-kernel damage; type IV—-tolerance to trichothecene toxins; type V-resistance to toxin accumulation [11,12]. In response to the presence of the pathogen, the host plant activates defense processes, e.g., alters the production of some biochemical components, such as soluble sugars, phenolic compounds, hormones, or reactive oxygen species (ROS) [13]. Sugars play a pivotal role in the immune processes, especially in pathogen attacks, by initiating a signal transduction pathway and regulating the osmotic potential [14-16]. Increased concentration of phenolic compounds is toxic to pathogens and prevents further infection. Phenolics are involved in the lignification of the cell wall, which increases the structural barrier that hinders the spread of the pathogen within the host plant tissue. The lignification may reduce the transfer of nutrients from the host plant cell to the pathogen [17]. Due to their toxic nature, phenolic compounds, such as phytoalexins, are considered activators of pathogen resistance genes and modulators of pathogen toxicity [18]. Another way to prevent pathogen infection is a mechanism that involves the production of enzymatic and non-enzymatic antioxidants, and scavenging of reactive oxygen species (ROS) [19]. The ROS includes non-radical molecules, such as hydrogen peroxide $\left(\mathrm{H}_{2} \mathrm{O}_{2}\right)$ and singlet oxygen $\left({ }^{1} \mathrm{O}_{2}\right)$, as well as free radicals, such as superoxide anion $\left(\mathrm{O}_{2}{ }^{-}-\right)$and hydroxyl radical $\left(\mathrm{OH}^{\bullet}\right)$ [20]. Reactive oxygen species can perform three functions: They can act as cell-damaging agents, signal transduction molecules, and can provide protection against pathogenic microbes [21]. Excessive production of ROS is often called an oxidative burst. Overproduction of ROS can lead to protein and chlorophyll oxidation, damage to nucleic acids, lipid peroxidation, or initiation of programmed cell death [22,23]. Reactive oxygen species accumulation is counteracted by the activation of enzymatic antioxidants, such as catalase (CAT), peroxidase (POX), superoxide dismutase (SOD), and non-enzymatic antioxidants, such as low molecular weight (LMW) phenolics and carotenoids [21,24,25]. Catalase is responsible for the decomposition of $\mathrm{H}_{2} \mathrm{O}_{2}$ into $\mathrm{H}_{2} \mathrm{O}$ and $\mathrm{O}_{2}$, as well as for 
the regulation of $\mathrm{H}_{2} \mathrm{O}_{2}$ concentration in plant tissues. This enzyme is involved in plant development, but also plays an important role in plant resistance to pathogens and aging processes [26]. Peroxidases have a similar function to CAT, as they are involved in scavenging ROS in response to pathogen-plant interactions. In addition, POXs are responsible for the oxidation of phenolics, making them more toxic towards pathogens, lignin biosynthesis, suberization, and growth of the plant cell walls [27]. Superoxide dismutase plays an equally pivotal role in maintaining redox balance and defense response in plants exposed to stress. Its task is to catalyze the dismutation of $\mathrm{O}_{2}{ }^{--}$and $\mathrm{HO}_{2}{ }^{\bullet}$ (hydroperoxide radical) to $\mathrm{H}_{2} \mathrm{O}_{2}$ and $\mathrm{H}_{2} \mathrm{O}$. Superoxide dismutase is the first line of defense against a pathogen attack and protects plants from oxidative stress [28]. Hydrogen peroxide also plays a significant role in pathogen defense. Thanks to its antimicrobial properties, it can induce local and systemic resistance to pathogen infection in plants [29].

Pathogen presence can also affect the level of chlorophyll pigments and their activity, resulting in altered efficiency of photosystem II (PS II) [30]. Similar observations were reported by other authors examining the photosynthetic pigment content after F. culmorum infection in tomato [31] and barley [32]. The investigated pathogen predominates in cooler areas of northern, central, and western Europe, and it infects wheat, barley, and oats [33]. Grain of durum wheat (Triticum turgidum L. subsp. durum (Desf.) Husn.) is used primarily in the production of pasta and to a lesser extent in the production of bread and groats. Although, durum wheat originates from the Mediterranean region and the countries of the Middle East is also very sensitive to F. culmorum [34]. Recent years have brought increased interest in durum wheat cultivation in Poland. Major problems with this crop include its high sensitivity to drought, soil salinity, cadmium accumulation, and Fusarium infections [34-37]. Durum wheat, as compared with common wheat (T. aestivum), is characterized by higher sensitivity to Fusarium infection. This is attributed to its morphological traits, such as early flowering, longer awn, another retention inside the floret, spike compactness, and genetic differences, such as the presence of type I rather than type II resistance genes $[38,39]$.

In the presented study, three durum wheat accessions were assessed in terms of resistance to Fusarium diseases at two stages of their ontogenesis: Two-week-old seedlings and full anthesis stage $-65 \mathrm{BBCH}$ scale [40]. The defense response of the studied durum genotypes included evaluation of the resistance degree in the seedlings by means of visual inspection of the leaves and roots, and fresh weight measurements. We also determined the content of total soluble carbohydrates, total soluble phenolics and cell wall-bound phenolics, chlorophyll pigments, hydrogen peroxide, and antioxidant enzymes activity. At the full anthesis stage, we visually evaluated the resistance to Fusarium head blight, and measured the content of mycotoxins (deoxynivalenol, nivalenol, T-2 toxin, and zearalenone), and yield parameters. The main objective of the study was to identify physiological or biochemical markers of resistance to F. culmorum at both developmental stages in three durum wheat accessions. The investigation was carried out on Polish line SMH87 and two Australian accessions: cv. 'Tamaroi' and $\mathrm{BC}_{5} \mathrm{Nax}_{2}$ line. The selected genotypes differed in the degree of resistance to salinity and were the subject of our earlier studies on cadmium accumulation in the grain of durum wheat [36,37].

\section{Results}

\subsection{Experiment I}

\subsubsection{Disease Rating (DR) and Fresh Weight (FW) Loss}

The visual disease rating (DR) included only the seedlings infected with F. culmorum, so control seedlings were not evaluated. In this experiment, the vigor of plant seedlings at the three-leaf stage was assessed. All analyses, described in Section 2.1., were done on material collected in this developmental stage. The leaves and roots of SMH87 line and cv. 'Tamaroi' showed higher sensitivity to the pathogen infection than those of the $\mathrm{BC}_{5} \mathrm{Nax}_{2}$ line (Figure 2). The highest percentage of leaf DR was observed in SMH87 plants, while the lowest in the $\mathrm{BC}_{5} \mathrm{Nax}_{2}$ line. Root infection results were similar in SMH87 and cv. 'Tamaroi'. 
Roots of $\mathrm{BC}_{5} \mathrm{Nax}_{2}$ were infected to the same degree as in $\mathrm{cv}$. 'Tamaroi', but lower than in SMH87.

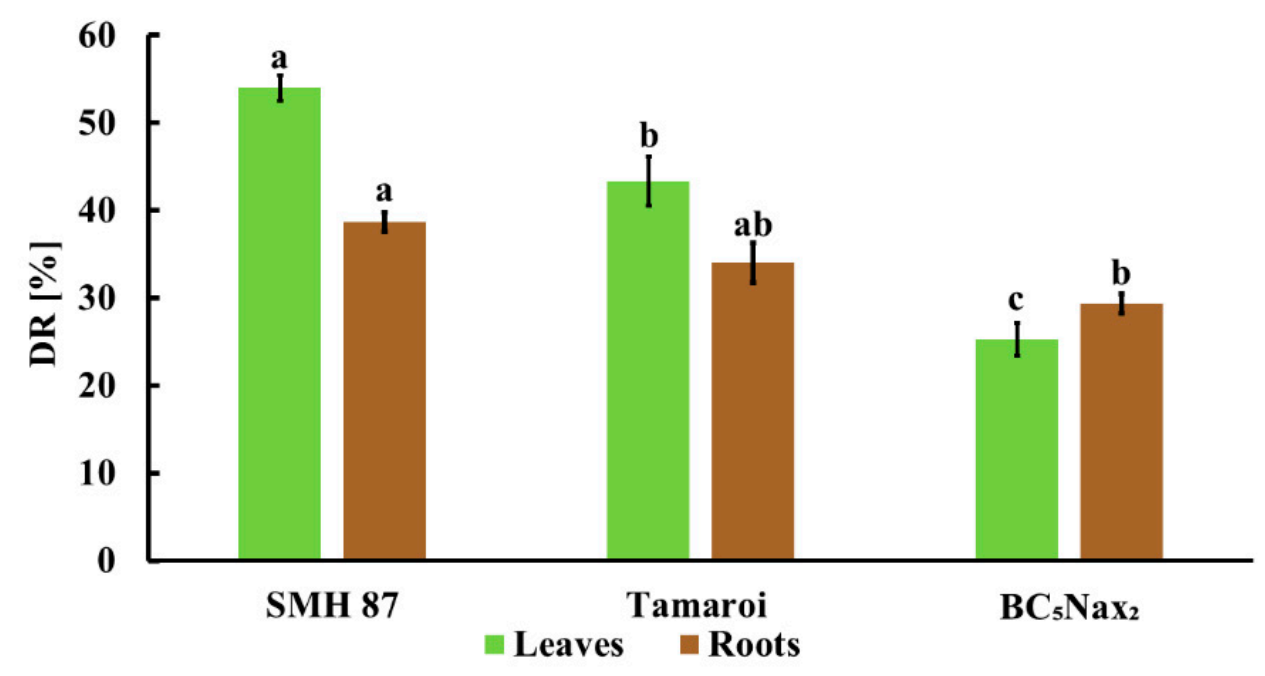

Figure 2. Disease rating (DR) in the leaves and roots of three durum wheat genotypes infected with F. culmorum. The values represent means $(n=30) \pm \mathrm{SE}$ (standard error). Different superscript letters $(a-c)$ for each organ indicate significant differences between means (Duncan's multiple range test; $p<0.05)$.

Fusarium culmorum infection negatively affected leaf and root FW in all studied accessions (Figure 3). The effects were more pronounced in the roots than in the leaves. In SMH87 and cv. 'Tamaroi' FW reduction of the infected leaves was greater than in $\mathrm{BC}_{5} \mathrm{Nax}_{2}$. Fusarium infection caused a 37\% decrease in leaf FW in both SMH87 and cv. 'Tamaroi' as compared with control. The infected roots of SMH87 and cv. 'Tamaroi' demonstrated a $66 \%$ decrease in FW in comparison with control. $\mathrm{BC}_{5} \mathrm{Nax}_{2}$ line did not show FW reduction in the infected leaves, but in the infected roots, FW loss amounted to $39 \%$ versus that of control.

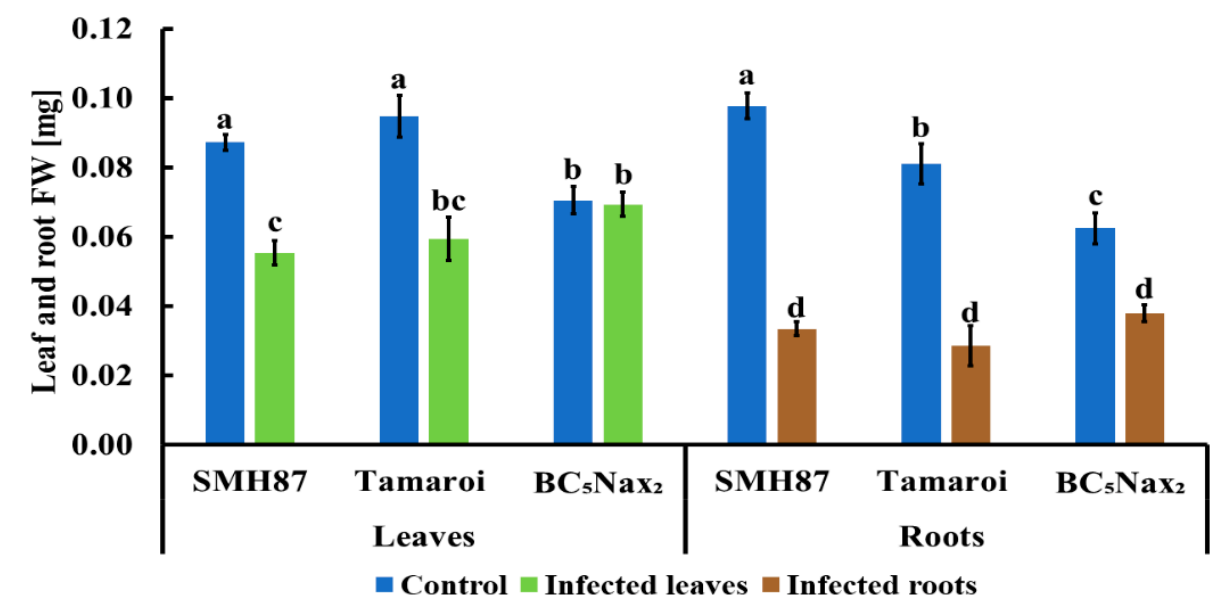

Figure 3. Effects of F. culmorum infection on fresh weight (FW) of the leaves and roots of three durum wheat accessions. The values represent means $(n=30) \pm$ SE. Different superscript letters $(a-d)$ for each organ indicate significant differences between means (Duncan's multiple range test; $p<0.05$ ).

\subsubsection{Chlorophyll $a, b$, and Carotenoid (Chla, $b$, and car) Content}

The infection reduced the contents of chlorophyll $a, b$, and carotenoids (Chl $a, b$, and car) in all studied durum wheat accessions (Figure 4A). The greatest decrease in all pigments was observed in SMH87 leaves. Chlorophyll $a$ content dropped by $48 \%$, Chl $b$ by $40 \%$, 
and carotenoids by $44 \%$ as compared with control plants. The other studied accessions also showed pigment content reduction in the infected plants; however, these differences, although significant, were not as drastic as in the SMH87 line.
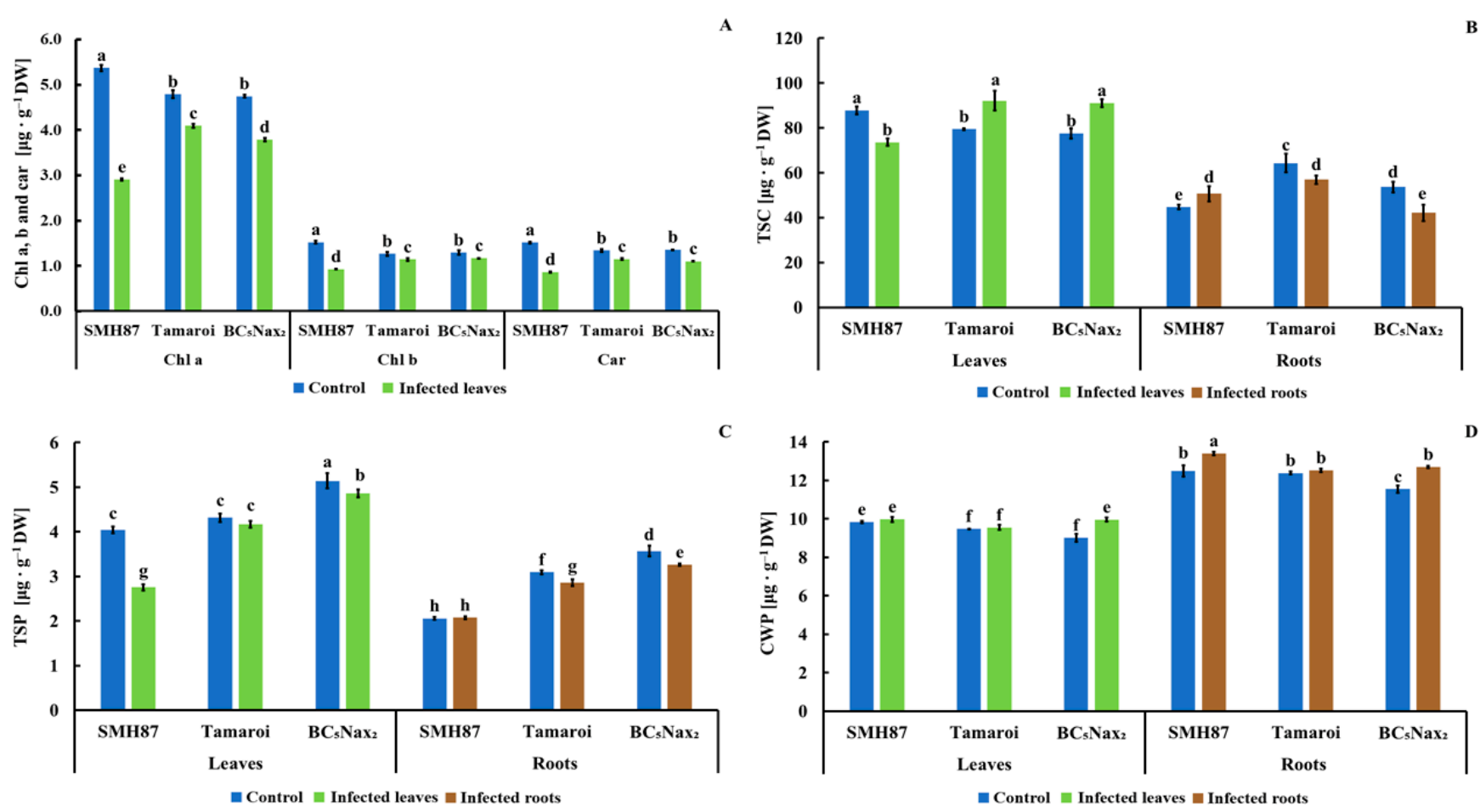

Figure 4. Effect of F. culmorum infection on the content of (A) chlorophyll $a, b(\mathrm{Chl} a, b)$ and carotenoids (Car), (B) total water-soluble carbohydrates (TSC), (C) total soluble phenolics (TSP), (D) cell wall-bound phenolics (CWP) in the leaves and roots of three durum wheat accessions. The values represent means $(n=30) \pm$ SE. Different superscript letters $(\mathrm{a}-\mathrm{h})$ for each organ indicate significant differences between means (Duncan's multiple range test; $p<0.05$ ).

\subsubsection{Total Soluble Carbohydrates (TSC)}

As a result of the infection, TSC content in SMH87 plants (Figure 4B) decreased in the leaves and increased in the roots, as compared with control. An opposite trend was observed in cv. 'Tamaroi' and $\mathrm{BC}_{5} \mathrm{Nax}_{2}$, where the infection triggered an increase in TSC in the leaves and a drop in the roots as compared with control.

\subsubsection{Total Soluble Phenolics (TSP)}

The studied genotypes differed in the content of total soluble phenolics (TSP) in the control and infected leaves and roots (Figure 4C). Line SMH87 showed a significant, almost $32 \%$ decrease of TSP content in the infected leaves, but no changes in the roots. In the infected leaves and roots of $\mathrm{BC}_{5} \mathrm{Nax}_{2}$ a reduction in TSP was observed, while in cv. 'Tamaroi' the infection decreased phenolic content in the roots. Total soluble phenolics levels in the leaves of this cultivar were unaffected by the infection.

\subsubsection{Cell Wall-Bound Phenolics (CWP)}

Fusarium infection boosted CWP only in the leaves of $\mathrm{BC}_{5} \mathrm{Nax}_{2}$ (Figure 4D). In the roots of SMH87 and $\mathrm{BC}_{5} \mathrm{Nax}_{2}$, an increase in CWP was observed upon inoculation. In other cases, the infection did not cause significant changes in the content of these compounds.

\subsubsection{Catalase (CAT) Activity}

The greatest increase in CAT activity is due to the infection was observed in SMH87 leaves. In cv. 'Tamaroi', it was diminished, and in the $\mathrm{BC}_{5} \mathrm{Nax}_{2}$ line, it was unaffected by the infection (Figure 5A). Catalase activity was considerably higher in control roots of cv. 
'Tamaroi' and $\mathrm{BC}_{5} \mathrm{Nax}_{2}$ than in the infected ones. There was no difference in CAT activity in the infected and control SMH87 roots.
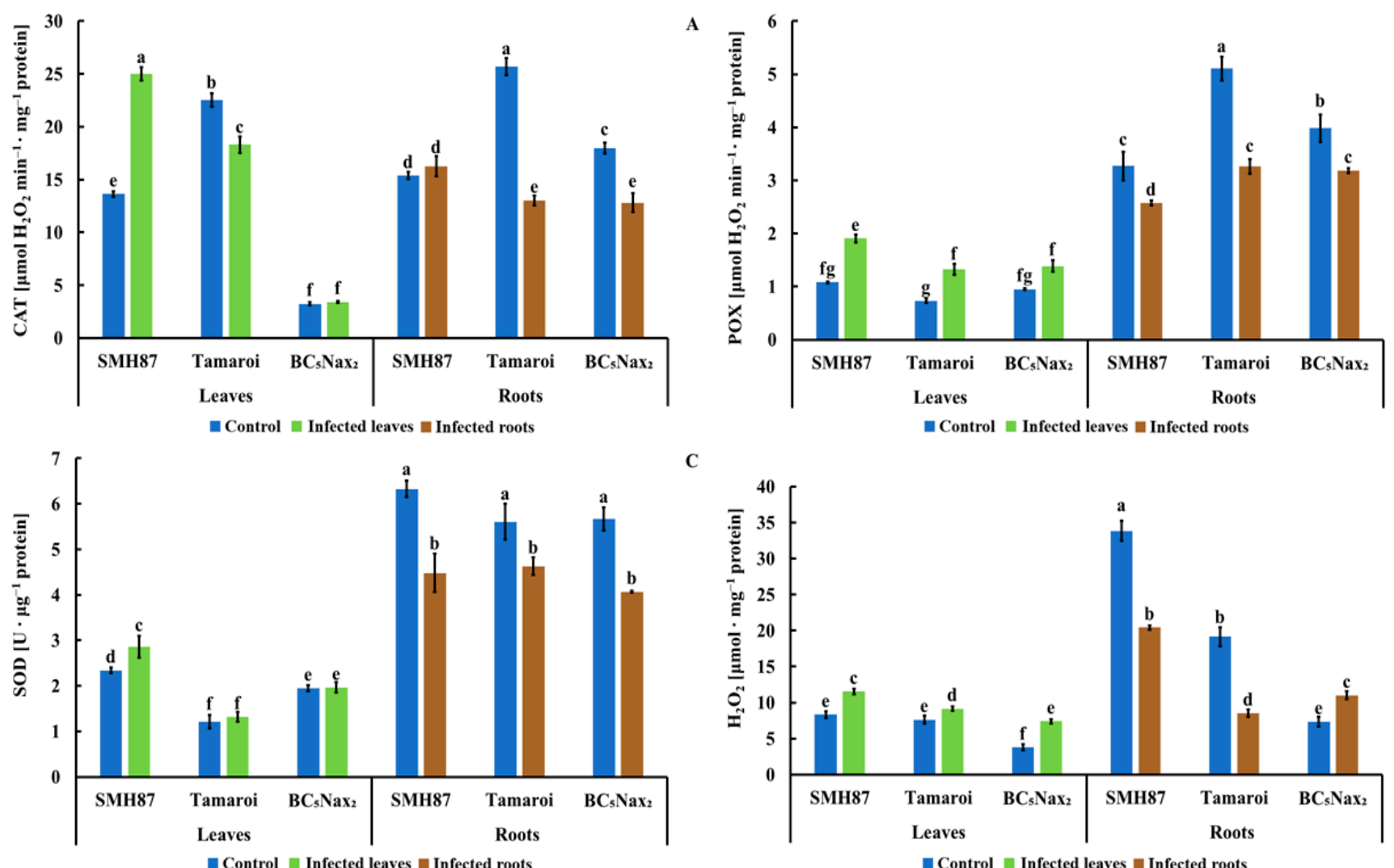

Figure 5. Effects of F. culmorum infection on catalase (A), peroxidases (B), and superoxide dismutase (C) activity, and $\mathrm{H}_{2} \mathrm{O}_{2}$ (D) content in the leaves and roots of three durum wheat accessions. The values represent means $(n=3) \pm \mathrm{SE}$. Different superscript letters $(\mathbf{a}-\mathbf{g})$ for each organ indicate significant differences between means (Duncan's multiple range test; $p<0.05)$.

\subsubsection{Peroxidases (POXs) Activity}

An increase in POXs activity was observed in the leaves of all infected genotypes (Figure 5B). The leaves of SMH87 and cv. 'Tamaroi' showed a 44\% increase in POXs activity as compared with control, while in $\mathrm{BC}_{5} \mathrm{Nax}_{2}$ leaves, this increase amounted to $31 \%$. In the roots ofSMH87, 'Tamaroi', and $\mathrm{BC}_{5} \mathrm{Nax}_{2}$, the infection brought about a significant decrease in POXs activity by 23,35 , and $19 \%$, respectively.

\subsubsection{Superoxide Dismutase (SOD) Activity}

Superoxide dismutase activity was significantly higher only in the infected leaves of the SMH87 line as an effect of Fusarium infection (Figure 5C). In the case of other accessions, the infection did not change SOD activity. In the infected roots of SMH87, cv. 'Tamaroi', and $\mathrm{BC}_{5} \mathrm{Nax}_{2}$ the infection decreased activity of this enzyme by $30 \%, 18 \%, 28 \%$, respectively.

\subsubsection{Hydrogen Peroxide $\left(\mathrm{H}_{2} \mathrm{O}_{2}\right)$ Content}

Hydrogen peroxide content increased in the leaves of all studied accessions as an effect of infection (Figure 5D). The highest increase in $\mathrm{H}_{2} \mathrm{O}_{2}$ level was noted in the infected leaves of $\mathrm{BC}_{5} \mathrm{Nax}_{2}$ plants. A rapid decrease in $\mathrm{H}_{2} \mathrm{O}_{2}$ content was noted in the infected roots of SMH87 (39\%) and cv. 'Tamaroi' (55\%), while in $\mathrm{BC}_{5} \mathrm{Nax}_{2}$ plants, the infection enhanced $\mathrm{H}_{2} \mathrm{O}_{2}$ level in the roots by $33 \%$ vs. control. 


\subsection{Correlation Analysis}

The disease symptoms assessed with the visual disease rating (DR) negatively correlated with Chla, $b$, and Car content, and with FW of the leaves and roots (Table 1).

Table 1. Pearson coefficients of linear correlation $(p<0.05)$ between the disease rating (DR) and chlorophyll $a, b(\mathrm{Chl} a, b)$, and carotenoid (Car) content and fresh weight (FW) of the leaves and roots.

\begin{tabular}{cccccc}
\hline Variable & Chl $\boldsymbol{a}$ & Chl $\boldsymbol{b}$ & Car & FW of Leaves & FW of Roots \\
\hline DR in leaves & -0.859 & -0.804 & -0.870 & -0.715 & -0.755 \\
\hline DR in roots & -0.891 & -0.811 & -0.898 & -0.672 & -0.821 \\
\hline
\end{tabular}

Significant correlations between $\mathrm{H}_{2} \mathrm{O}_{2}$ content and the investigated enzymes were found (Table 2).

Table 2. Pearson coefficients of linear correlation $(p<0.05)$ between $\mathrm{H}_{2} \mathrm{O}_{2}$ content in the leaves and roots and the activity of catalase (CAT), peroxidases (POX), superoxide dismutase (SOD), as well as total soluble phenolic (TSP) and cell wall-bound phenolic (CWP) content in the leaves and roots of three accessions of durum wheat.

\begin{tabular}{|c|c|c|}
\hline Variable & Leaves & Roots \\
\hline CAT in leaves & 0.710 & ns \\
\hline CAT in roots & ns & ns \\
\hline POX in leaves & 0.688 & ns \\
\hline POX in roots & ns & ns \\
\hline SOD in leaves & ns & ns \\
\hline $\mathrm{SOD}$ in roots & ns & 0.613 \\
\hline TPC in leaves & -0.863 & ns \\
\hline $\mathrm{TPC}$ in roots & -0.763 & -0.658 \\
\hline CWP in leaves & 0.679 & ns \\
\hline CWP in roots & 0.861 & ns \\
\hline
\end{tabular}

In the leaves, CAT and POX positively correlated with $\mathrm{H}_{2} \mathrm{O}_{2}$ content. This relationship was not observed in the roots. Superoxide dismutase activity correlated positively with $\mathrm{H}_{2} \mathrm{O}_{2}$ only in the roots $(\mathrm{r}=0.613, p<0.05)$, proving that the higher SOD activity, the more $\mathrm{H}_{2} \mathrm{O}_{2}$ was produced. In the leaves, TPC content negatively correlated with $\mathrm{H}_{2} \mathrm{O}_{2}$ levels, while TPC content in the roots negatively correlated with $\mathrm{H}_{2} \mathrm{O}_{2}$ concentration in both studied organs (Table 2.). Significant correlation between TSP and TSC $(r=0.63118$, $p<0.05)$ was found.

\subsection{Experiment II}

\subsubsection{Fusarium Head Blight Index (FHBi) and Yield Parameters}

Index FHBi showed a significant difference between the studied genotypes regarding F. culmorum resistance (Table 3). The time after infection on the spikes significantly impacted the disease development. The research revealed the fastest and the strongest spike infection $(10 \%)$ in the SMH87 line seven days after the first inoculation. After 14 days, a $71 \%$ increase in FHBi of SMH87 spikes vs. the first evaluation was observed. The spike inoculation with Fusarium spores significantly reduced the amount of grain per spike in all studied genotypes (Table 3). A significantly higher grain reduction occurred in SMH87, where it was $83 \%$ greater than in control. A strong reduction in grain number $(64 \%)$ was also observed in cv. 'Tamaroi'. 
Table 3. Fusarium head blight index (FHBi) evaluated 7 and 14 days (DAI 7 and DAI 14) after spike inoculation with F. culmorum and yield components of three durum wheat genotypes.

\begin{tabular}{|c|c|c|c|c|c|c|c|}
\hline \multirow{2}{*}{ Accession } & \multirow{2}{*}{ Treatment } & \multicolumn{2}{|c|}{ FHBi [\%] } & \multirow{2}{*}{$\begin{array}{l}\text { Amount of Grain } \\
\text { Per Spike }\end{array}$} & \multirow{2}{*}{$\begin{array}{l}\text { Grain Mass } \\
\text { Per Spike (g) }\end{array}$} & \multirow{2}{*}{$\begin{array}{c}\text { Mass of One piece } \\
\text { of Grain (g) }\end{array}$} & \multirow{2}{*}{ MTS (g) } \\
\hline & & DAI 7 & DAI 14 & & & & \\
\hline \multirow{2}{*}{ SMH87 } & Control & - & - & $12.3 \pm 1.4^{b}$ & $0.328 \pm 0.048^{b}$ & $0.050 \pm 0.003^{b}$ & $36.437 \pm 0.319^{b}$ \\
\hline & Inoculum & $10.1 \pm 1.8^{\mathrm{a}}$ & $34.7 \pm 4.1^{\mathrm{a}}$ & $2.0 \pm 0.4^{\mathrm{d}}$ & $0.055 \pm 0.016^{\mathrm{d}}$ & $0.012 \pm 0.003^{\mathrm{d}}$ & $15.603 \pm 0.348^{d}$ \\
\hline \multirow{2}{*}{ Tamaroi } & Control & - & - & $16.8 \pm 1.2^{\mathrm{a}}$ & $0.459 \pm 0.047^{a}$ & $0.049 \pm 0.005^{b}$ & $37.674 \pm 1.077^{b}$ \\
\hline & Inoculum & $4.8 \pm 0.9^{b}$ & $8.3 \pm 1.1^{b}$ & $5.9 \pm 1.0^{\mathrm{d}}$ & $0.099 \pm 0.019^{\mathrm{d}}$ & $0.016 \pm 0.004^{\mathrm{d}}$ & $16.200 \pm 1.853^{\mathrm{d}}$ \\
\hline \multirow{2}{*}{$\mathrm{BC}_{5} \mathrm{Nax}_{2}$} & Control & - & - & $13.6 \pm 1.2^{b}$ & $0.355 \pm 0.042^{b}$ & $0.061 \pm 0.004^{\mathrm{a}}$ & $51.763 \pm 0.602^{a}$ \\
\hline & Inoculum & $3.0 \pm 0.7^{b}$ & $10.7 \pm 1.9^{b}$ & $10.9 \pm 1.1^{c}$ & $0.209 \pm 0.023^{c}$ & $0.028 \pm 0.004^{c}$ & $28.209 \pm 1.905^{c}$ \\
\hline
\end{tabular}

Values represent means \pm SE. Fusarium head blight index (FHBi), amount of grain, grain mass per spike, and mass of one piece of grain were calculated in 45 replicates, while mass of one thousand seeds (MTS) were calculated in 3 replicates. Different superscript letters (a-d) FHBi and yield parameters indicate significant differences between means within columns (Duncan's multiple range test; $p<0.05$ ).

$\mathrm{BC}_{5} \mathrm{Nax}_{2}$ line showed the lowest reduction of grain yield per spike in the inoculated plants. The analysis of yield parameters showed significant differences in grain mass per spike and in the mass of one piece of grain, as well as MTS of the control and inoculated plants (Table 3). A significantly higher $(83 \%)$ reduction of grain mass per spike was observed in $\mathrm{SMH} 87$ plants. $\mathrm{BC}_{5} \mathrm{Nax}_{2}$ plants showed a significantly lower (by $40 \%$ ) reduction in grain mass per spike as compared with the other studied accessions. Analyses of the mass of one piece of grain and of one thousand grains revealed significant differences between the studied accessions (Table 3). A significant loss of a single grain mass was observed in the SMH87 line, dropping by $75 \%$ vs. control plants. A $45 \%$ reduction in MTS was observed in $\mathrm{BC}_{5} \mathrm{Nax}_{2}$ plants. This genotype showed the lowest MTS reduction, while the highest MTS reduction was seen in SMH87.

\subsubsection{Mycotoxin Content}

Trace amounts of DON and ZEN were found in the grain of all control plants, while the concentration of T-2 was ten times higher (Table 4). The amount of NIV in control plants of 'Tamaroi' and $\mathrm{BC}_{5} \mathrm{Nax}_{2}$ was four times higher than that in SMH87. The infection considerably increased the levels of NIV, DON, and T-2 toxins. The highest amount of NIV was recorded in cv. 'Tamaroi' grain after inoculation and it was six times higher than that of the control. In the grain of the infected SMH87, the level of this toxin was 18 times higher than in control, while in the infected $\mathrm{BC}_{5} \mathrm{Nax}_{2}$ plants-four times higher. In $\mathrm{BC}_{5} \mathrm{Nax}_{2}$ grain, NIV level after inoculation increased four times as compared with control. As in the case of NIV, cv. 'Tamaroi' grain contained the highest level of DON. The grain content of ZEN was the lowest among the other studied toxins. Inoculation did not increase ZEN content in SMH87 seeds, while in cv. 'Tamaroi' and $\mathrm{BC}_{5} \mathrm{Nax}_{2}$, the level of this toxin was more than six times higher than in the control. In all cases, inoculation slightly increased the content of $\mathrm{T}-2$ in the seeds as compared with that of the control. The highest increase in T-2 was found in cv. 'Tamaroi' $(2.3 \times)$, while in SMH87 and $\mathrm{BC}_{5} \mathrm{Nax}_{2}$, the increase was 1.64 and $1.75 \times$, respectively. To summarize, cv. 'Tamaroi' showed the highest toxin accumulation in grain.

Table 4. Content $\left[\mu \mathrm{g} \mathrm{kg}^{-1}\right]$ of nivalenol (NIV), deoxynivalenol $\left(\mathrm{DON}^{1}\right), \mathrm{T}-2$ toxin $(\mathrm{T}-2)$, and zearalenone $\left(\mathrm{ZEN}^{2}\right)$ in the grain after F. culmorum spike inoculation.

\begin{tabular}{|c|c|c|c|c|c|}
\hline Accession & Treatment & NIV & DON $^{1}$ & $\mathrm{ZEN}^{2}$ & $\mathrm{~T}-2$ \\
\hline \multirow{2}{*}{ SMH87 } & Control & $0.098 \pm 0.008^{\mathrm{d}}$ & $0.093 \pm 0.002^{\mathrm{c}}$ & $0.008 \pm 0.001^{\mathrm{e}}$ & $0.101 \pm 0.003^{\mathrm{e}}$ \\
\hline & Inoculum & $1.785 \pm 0.073^{b}$ & $5.763 \pm 0.137^{b}$ & $0.002 \pm 0.001^{\mathrm{e}}$ & $0.166 \pm 0.013^{c}$ \\
\hline \multirow{2}{*}{ Tamaroi } & Control & $0.414 \pm 0.021^{c}$ & $0.037 \pm 0.003^{c}$ & $0.004 \pm 0.001^{\mathrm{d}}$ & $0.136 \pm 0.006^{d}$ \\
\hline & Inoculum & $2.474 \pm 0.109^{a}$ & $8.052 \pm 0.373^{a}$ & $0.031 \pm 0.001^{b}$ & $0.317 \pm 0.010^{a}$ \\
\hline \multirow{2}{*}{$\mathrm{BC}_{5} \mathrm{Nax}_{2}$} & Control & $0.406 \pm 0.026^{c}$ & $0.047 \pm 0.002^{c}$ & $0.022 \pm 0.002^{c}$ & $0.126 \pm 0.004^{d}$ \\
\hline & Inoculum & $1.765 \pm 0.018^{b}$ & $6.208 \pm 0.318^{b}$ & $0.138 \pm 0.002^{\mathrm{a}}$ & $0.221 \pm 0.005^{b}$ \\
\hline
\end{tabular}

Values represent means $(n=3) \pm$ SE. Different superscript letters (a-e) within columns indicate significant differences between means (Duncan's multiple range test; $p<0.05)$. DON ${ }^{1}$ total amount of deoxynivalenol (DON), and 3-acetyldeoxynivalenol (3AcDON) and 15 -acetyldeoxynivalenol (15AcDON); ZEN ${ }^{2}$ total amount of zearalenone (ZEN); alpha-Zearalanol ( $\left.\alpha-Z A L\right)$, beta-Zearalanol ( $\left.\beta-Z A L\right)$; alpha-Zearalanol $(\alpha-Z E L)$ and beta-Zearalenol $(\beta-Z E L)$. 


\subsubsection{Correlation Analysis}

Fusarium head blight index (FHBi) evaluated 7 and 14 days after inoculation negatively correlated with the number of seeds and their mass (Table 5). The content of NIV and DON significantly decreased all studied yield parameters, while ZEN reduced only the mass of a single grain. No correlation between the content of T-2 and the evaluated yield parameters was found. The latter two results can be explained by low content of both toxins.

Table 5. Pearson's coefficients of linear correlation $(p<0.05)$ between Fusarium head blight index (FHBi) evaluated 7 and 14 days after inoculation (DAI 7 and DAI 14), mycotoxin content in grain and yield parameters.

\begin{tabular}{cccccccc}
\hline Variable & FHBi DAI 7 & FHBi DAI 14 & NIV & DON $^{1}$ & ZEN $^{2}$ & T-2 \\
\hline Number of grain per spike & -0.591 & -0.575 & -0.503 & -0.549 & $\mathrm{~ns}$ & $\mathrm{~ns}$ \\
\hline Mass of grain per spike [g] & -0.589 & -0.576 & -0.566 & -0.612 & $\mathrm{~ns}$ & $\mathrm{~ns}$ \\
\hline Mass of a single grain [g] & -0.754 & -0.743 & -0.863 & -0.864 & -0.714 & $\mathrm{~ns}$ \\
\hline MTS [g] & -0.741 & -0.848 & -0.551 & -0.589 & $\mathrm{~ns}$ & $\mathrm{~ns}$ \\
\hline
\end{tabular}

$\mathrm{DON}^{1}$ total amount of deoxynivalenol (DON), 3-acetyldeoxynivalenol (3AcDON) and 15-acetyldeoxynivalenol (15AcDON); ZEN ${ }^{2}$ total amount of zearalenone (ZEN); alpha-Zearalanol ( $\left.\alpha-Z A L\right)$, beta-Zearalanol ( $\left.\beta-Z A L\right)$; alpha-Zearalanol ( $\alpha-Z E L)$ and beta-Zearalenol ( $\beta-Z E L)$; MTS-mass of thousand seeds; ns-values not significant.

Strong correlation was detected between the visual assessment of Fusarium head blight index (FHBi) evaluated in both terms ( 7 and 14 days after infection) and the grain content of all investigated mycotoxins, except for T-2 (Table 6). Index FHBi positively correlated with the content of DON and NIV, while in the case of ZEN, a significant correlation was found only seven days after the infection.

Table 6. Pearson's coefficients of linear correlation $(p<0.05)$ between Fusarium head blight index (FHBi) evaluated 7 and 14 days after the inoculation (DAI 7 and DAI 14) and mycotoxin content in the grain.

\begin{tabular}{ccccc}
\hline Variable & NIV & DON $^{\mathbf{1}}$ & ZEN $^{2}$ & T-2 Toxin $^{2}$ \\
\hline FHBi DAI 7 & 0.731 & 0.733 & 0.484 & ns \\
\hline FHBi DAI 14 & 0.630 & 0.632 & ns & ns \\
\hline
\end{tabular}

$\mathrm{DON}^{1}$ total amount of deoxynivalenol (DON), 3-acetyldeoxynivalenol (3AcDON) and 15-acetyldeoxynivalenol $(15 \mathrm{AcDON}) ; \mathrm{ZEN}^{2}$ total amount of zearalenone (ZEN); alpha-Zearalanol ( $\left.\alpha-\mathrm{ZAL}\right)$, beta-Zearalanol $(\beta-\mathrm{ZAL})$; alpha-Zearalanol ( $\alpha-Z E L)$ and beta-Zearalenol ( $\beta-Z E L)$; MTS-mass of thousand seeds; ns-values not significant.

\section{Discussion}

Fusarium culmorum attacks plants at various developmental stages. The pathogenesis is responsible for the formation of seedling blight and root rot, which limit seedling emergence and plant development [32]. In our experiment, the infection caused a darkening of the roots and slower leaf growth. The studied genotypes differed more in the degree of leaf than root infestation. SMH87 line was the most, and $\mathrm{BC}_{5} \mathrm{Nax}_{2}$ the least heavily infested. Medium infestation degree was observed in cv. 'Tamaroi'. This result was surprising, since the genotypes originating from a much warmer and drier climate were less severely infected than the original genotype from Poland. The infection degree was visible in leaf FW loss: $\mathrm{BC}_{5} \mathrm{Nax}_{2}$ genotype did not show changes in fresh leaf weight, while the decrease in root weight, although significant, was the smallest among the studied genotypes. Similar results were obtained by Grey and Mathre [41] in barley, by Wojciechowski et al. [42] in winter wheat, and by Warzecha et al. [43] in oats. These authors suggest that the most severe damage caused by Fusarium seedling blight appeared in the roots. It indicates that visual evaluation of root infestation may be more useful than leaf assessment. According to Malalaseker et al. [44] and Knudsen et al. [45], root rot may also develop, due to a prior infestation of hypocotyls and shoots. Root infection negatively affects proper plant 
development and disturbs basic physiological processes, such as distribution of assimilates, water uptake and transport, and soil mineral absorption. These disturbances result in reduced seedling vigor and interrupted growth which negatively affects grain quality and yield.

Fungal mycelium penetrates the host-plant cells and limits access to nutrients and water. Released toxins disrupt metabolic and physiological processes. This leads to the reduction of photosynthetic pigment content and disturbances of photosynthesis [44]. Our study demonstrated that F. culmorum infection significantly decreased the content of chlorophyll $a, b$, and carotenoids in the leaves. Similar observations were published by other researchers examining the content of photosynthetic pigments after F. culmorum infection in tomato [31] or barley [32]. In our study, the results of visual assessment of DR in the leaves and roots negatively correlated with the content of Chla, $b$, and Car.

Soluble sugars play an important role in plant development and metabolism, and therefore, their content fluctuates during plant infection. Soluble sugars in the host-plant cells are a source of carbon for the pathogen [46-48]. Sucrose was shown to induce defense mechanisms in the infected cells. The hexose, through signal transduction by hexokinase, increases the production of peroxidases and proteins directly related to pathogenesis $[14,16]$. Soluble sugars, as compounds with higher osmotic potential, limit the spread of the infection. Moreover, they isolate healthy cells from the infected ones and protect them against water loss [49]. Our analyzes of TSC showed that infection significantly increased TSC content in cv. 'Tamaroi' and $\mathrm{BC}_{5} \mathrm{Nax}_{2}$ leaves and decreased TSC levels in the roots. A contrary trend was observed in the leaves and roots of SMH87 line. Warzecha et al. [32] noted an increased sugar content in the leaves and their decrease in the roots of barley infected by F. culmorum. Morkunas et al. [16] reported that increased content of soluble sugars supported the resistance of Lupinus luteus L. to F. oxysporum infection, while Gaudet et al. [15] observed a similar correlation in wheat infested by snow mold fungi. Bani et al. [50] suggested that Fusarium species infection during seed germination disrupted sugar distribution between cotyledons and the tissues of embryo axis in the germinating seeds. Formela-Luboińska et al. [51] reported that soluble carbohydrates reduced sporulation of F. oxysporum f. sp. lupini and limited the production of moniliformin toxin synthesized by this Fusarium species. In our study, the more resistant Australian accessions (cv. 'Tamaroi', $\mathrm{BC}_{5} \mathrm{Nax}_{2}$ ) showed higher sugar content in the leaves of infected seedlings than Polish SMH87. Our research demonstrated that sugar content in the leaves was a stronger indicator of F. culmorum resistance than that in the roots.

Synthesis of phenolic compounds is a well-known defense response to pathogen attack. Their biosynthesis occurs both before and after the infection [52]. The defensive role of phenolics in fungal infections in plants was confirmed in our previous studies [53-55]. The phenolic compounds involved in the immune response to pathogen attack include salicylic and chlorogenic acids. Salicylic acid controls the content of the signal molecule hydrogen peroxide $\left(\mathrm{H}_{2} \mathrm{O}_{2}\right)$ responsible for plant resistance to environmental stresses. Salicylic acid activates superoxide dismutase (SOD), which boosts $\mathrm{H}_{2} \mathrm{O}_{2}$ production and stimulates the synthesis of pathogenesis related proteins (PR)—chitinases and glucanases that decompose the cell wall of the fungal hyphae [56,57]. Salicylic acid participates in systemic acquired resistance (SAR). This reaction is triggered in the case of biotrophic fungi infection. The fungi from Fusarium species are classified as hemibiotrophic ones, which means that the pathogens initially behave like biotrophic fungi and then switch on to the optional parasitization mode [52]. Another group of compounds participating in the immune response to pathogens is phytoalexins, i.e., low molecular weight phenolics. They are derivatives of benzoic acid, stilbene, coumarin or quercetin $[58,59]$. The synthesis of phenolic compounds requires a large energy input, and therefore, it depends on the accumulation of the number of soluble sugars in the cells. We confirmed this correlation in our experiments. High correlation $(\mathrm{r}=0.631 ; p<0.05)$ between TSC and TPC may indicate the plant defense response to the infection consisting in the increase of TSC consumption for ATP synthesis and further use of this energy in the synthesis of phenolics. SMH87 
plants, more sensitive to F. culmorum, showed a significant decrease in the phenolic content in the leaves as compared with the other accessions. Contrary to that, the most resistant $\mathrm{BC}_{5} \mathrm{Nax}_{2}$ line was characterized by the highest content of phenolics in the leaves and roots of the control and infected seedlings. Hakulinen et al. [60] suggested that the lowered content of phenolics may be caused by the synthesis of lignin that is a polymer of oxidized phenolic alcohols. Lignin fortifies cell walls making them difficult for fungal hyphae to colonizing the host plant [61,62]. Datta and Lal [63] and Noman et al. [64] reported this phenomenon as a hypersensitivity reaction initiated as a plant defense mechanism to developing an infection. In our experiment, a decrease in leaf TPC was associated with higher content of cell-wall-bound phenolic compounds (CWP) only in $\mathrm{BC}_{5} \mathrm{Nax}_{2}$. The same line revealed a relationship between decreased root TPC and increased accumulation of CWP. The leaf CWP content positively correlated with the content of $\mathrm{H}_{2} \mathrm{O}_{2}(\mathrm{r}=0.679$; $p<0.05)$. In the leaves, TPC content negatively correlated with $\mathrm{H}_{2} \mathrm{O}_{2}$ levels, while TPC content in the roots negatively correlated with $\mathrm{H}_{2} \mathrm{O}_{2}$ concentration in both studied organs. These negative correlations may suggest that during Fusarium infection, TPC acted as antioxidants and possibly reduced $\mathrm{H}_{2} \mathrm{O}_{2}$ amount.

Antioxidant enzymes, such as CAT, POXs, and SOD, form the first line of defense against ROS during the entire pathogenesis [65-67]. Superoxide dismutase (SOD) is responsible for the dismutation of the superoxide radicals to molecular oxygen and hydrogen peroxide. CAT and POX decompose $\mathrm{H}_{2} \mathrm{O}_{2}$. Some studies reported that Fusarium infections boosted the activity of the antioxidant enzymes [68-70]. In the investigated wheat seedlings, we detected greater POX and SOD activity in the roots than in the leaves. It can be explained by the fact that the in vitro infection started in the roots growing in the infected medium. In the roots we observed a correlation between SOD activity and $\mathrm{H}_{2} \mathrm{O}_{2}$ accumulation $(\mathrm{r}=0.613 ; p<0.05)$, while in the leaves there was a correlation between CAT and POX activity and $\mathrm{H}_{2} \mathrm{O}_{2}(\mathrm{r}=0.710$ and $\mathrm{r}=0.688 ; p<0.05$, respectively). We recorded high negative correlation between TPC content and CAT and POX activity in the leaves $(\mathrm{r}=-0.788$ and $\mathrm{r}=-0.515 ; p<0.05$, respectively). These results may suggest a competition between antioxidant enzymes and phenolic compounds for $\mathrm{H}_{2} \mathrm{O}_{2}$, which can indicate the antioxidant properties of phenolics. We reported higher activity of the antioxidant enzymes and higher levels of $\mathrm{H}_{2} \mathrm{O}_{2}$ in the control leaves than in the control roots. The infection decreased the activity of the antioxidant system in the roots, but not in the leaves. The enzyme activity poorly differentiated the studied accessions regarding their resistance to F. culmorum. Only CAT activity was twofold higher in the infected SMH87 leaves, considered by us to be more sensitive to Fusarium, while in cv. 'Tamaroi' and $\mathrm{BC}_{5} \mathrm{Nax}_{2}$ line this activity was lower or remained unchanged. Płażek and Żur [71] indicated that low activity of CAT could be a marker of a plant resistance to a fungal infection, as CAT decomposes $\mathrm{H}_{2} \mathrm{O}_{2}$ that is necessary for the defense as a signal molecule.

Fusarium head blight causes huge yield losses in cereals, reaching over $40 \%$. The disease reduces grain yield, its mass, nutritional value and leads to grain contamination with mycotoxins [6]. Our research confirmed that spike infection not only reduces the grain mass, but also lowers the final yield. The reduction of yield parameters is also associated with high concentrations of mycotoxins in the grain. Negative correlation between the examined yield parameters (amount of grain per spike, mass of grain per spike, mass of a single grain, and mass of thousand seeds) and the content of NIV and DON suggest the reduction of the yield is mainly, due to accumulated toxins. ZEN content only affected the mass of a single grain, and we found no relationships between T-2 toxin and the yield. The visual assessment of spike infestation degree (FHBi) was performed at two terms: Seven and fourteen days after infection. In both terms, FHBi highly negatively correlated with the yield parameters. It could be stated that $\mathrm{FHBi}$, especially 7 days after the infection, is a reliable method to determine cereal resistance to the infection, as confirmed by other studies [72,73].The statistical analysis showed a strong correlation between FHBi 7 and 14 days after the infection, and DON accumulation in the grain $(\mathrm{r}=0.733, \mathrm{r}=0.632, p<0.05$, respectively), and NIV content $(\mathrm{r}=0.731, \mathrm{r}=0.630, p<0.05$, 
respectively). A similar relationship between FHBi and DON accumulation was observed by Haidukowski et al. [74] in common wheat. Nowicki et al. [75] and Pascale et al. [76] claimed that FHBi can be used to predict the grain contamination degree with mycotoxins before performing detailed analyses. In our research, we used NIV-chemotype isolate of F. culmorum, which is considered a milder Fusarium chemotype than DON-chemotype or acetyl derivatives (3AcDON, 15AcDON) [77,78]. Desjardin and Plattner [79] reported that F. culmorum NIV-chemotypes can produce DON, but in amounts $<1 \%$ of NIV, while DON-chemotypes are not capable of producing NIV [80]. In our experiments, we observed increased level of DON in relation to NIV, which contradicted the hypothesis presented by Dejsrdin and Plattner [79].

\section{Materials and Methods}

\subsection{Plant Material and Experimental Design}

Two experiments were performed in 2020 . The first was an in vitro assay testing the plant resistance to Fusarium, and the other involved plants at the anthesis stage grown in an open foil tunnel. Three durum wheat accessions differing in salt-stress tolerance were used: Polish moderately sensitive SMH87 line (courtesy of Dr. Jarosław Bojarczuk, Plant Breeding Centre in Smolice, IHAR Group, Poland), sensitive Australian cultivar 'Tamaroi', and resistant $\mathrm{BC}_{5} \mathrm{Nax}_{2}$ line (courtesy of Dr. Richard A. James, CSIRO Plant Industry, Acton, Australia). These accessions were investigated in previous studies on durum wheat tolerance to salinity and cadmium.

\subsubsection{Preparation of Fusarium culmorum Isolate}

In both experiments, the plants or seeds were infected with IPO348-01 nivalenol chemotype mycelium of F. culmorum from the Plant Breeding Institute, Wageningen (Netherland). Mycelium box test was performed in in vitro conditions on seedlings grown on inoculated Potato Dextrose Agar (PDA) medium (Sigma-Aldrich, Poznań, Poland). The mycelium was grown in a microbiological thermostatic chamber (ST 5 Smart, Pol-Aura Aparatura, Wodzisław Ślaski, Poland) at $21^{\circ} \mathrm{C}$, in darkness for seven days [32]. The mycelium production for the open tunnel experiment followed the method described by Wiśniewska et al. [81]. An Erlenmeyer glass flask $\left(250 \mathrm{~cm}^{3}\right)$ was filled with $50 \mathrm{~g}$ of spring wheat seeds, and $15 \mathrm{~cm}^{3}$ of water $\mathrm{w}$ added to obtain $40 \%$ humidity. After $24 \mathrm{~h}$, the seeds were autoclaved at $101325 \mathrm{~Pa}$, at $121^{\circ} \mathrm{C}$ for $30 \mathrm{~min}$ and then cooled. The infection was initiated by transferring three $1.5 \mathrm{~cm}$ discs of PDA medium. The glass flasks were placed in the microbiological thermostatic chamber (ST 5 Smart, Pol-Aura Aparatura, Wodzisław Ślaski, Poland), and the mycelium was growing at $20 \pm 1{ }^{\circ} \mathrm{C}$ for five to six weeks in darkness. The flasks were shaken thoroughly every day to prevent sticking the grain to the glass, and to also provide uniform inoculation of the grain.

\subsubsection{Experiment I-Box Test Assay}

This experiment was performed on the seedlings grown in Magenta GA-7 Boxes (Sigma-Aldrich, Poznań, Poland) under sterile conditions. The boxes were filled with $20 \mathrm{~cm}^{3}$ of MS medium [82]. Discs (5 mm) of PDA medium overgrown with Fusarium mycelium were cut and transferred into magenta boxes on MS medium (five discs per box). The seeds were surface disinfected in $20 \%$ commercial bleach (active ingredient sodium hypochlorite) for $20 \mathrm{~min}$, rinsed three times for $2 \mathrm{~min}$ with sterile water, and transferred into Petri dishes lined with wetted sterile filter paper for $24 \mathrm{~h}$ germination. The germinating seeds (five seeds per Magenta-Box) were placed on mycelium discs. The control seeds were placed on PDA medium discs free of the pathogen (Figure 6). The experiment was performed in six replicates for each accession/treatment (magenta with control and inoculated seeds) combination. Vegetation in both treatments was conducted on MS medium. Vegetation conditions were maintained for 14 days in a growth chamber at $22 / 20{ }^{\circ} \mathrm{C}$ (day/night), the light intensity of $150 \mu \mathrm{mol} \mathrm{m}{ }^{-2} \cdot \mathrm{s}^{-1}$ PPFD (Photosynthetic Photon Flux Density) and $12 \mathrm{~h} / 12 \mathrm{~h}$ (day/night) photoperiod with $100 \%$ air humidity. 


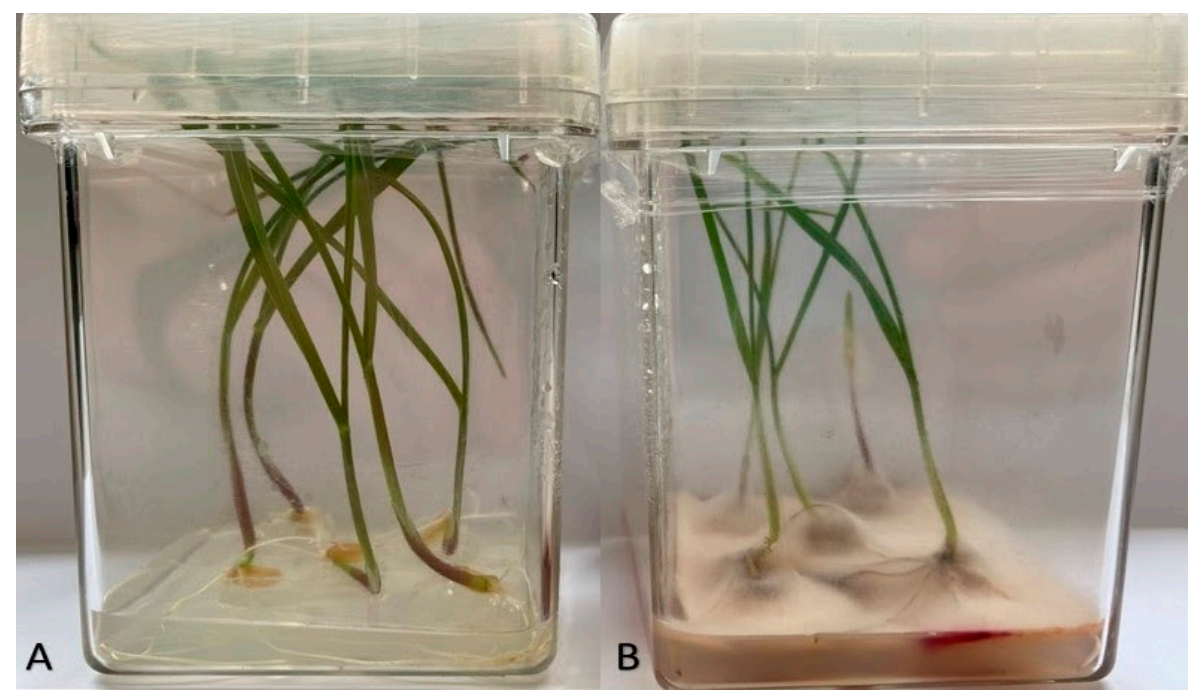

Figure 6. Two-week old durum wheat seedlings growing in pathogen-free medium (A) and the medium infected with F. culmorum medium (B).

Two weeks after inoculation, the leaves and roots were collected separately, weighed, and frozen in liquid nitrogen. The subsequent analyses involved: Visual disease rating (DR), chlorophyll $a, b$, and carotenoid content (Chl $a, b$, and car), total soluble carbohydrate content (TSC), the content of total phenolic compounds (TPC), and cell wall-bound phenolics (CWP), antioxidant enzyme activities, hydrogen peroxide content $\left(\mathrm{H}_{2} \mathrm{O}_{2}\right)$, and fresh weight (FW) of leaves and roots.

\subsubsection{Experiment II-Open Foil Tunnel}

The experiment was carried out in semi-controlled conditions in an open foil tunnel. The seeds were sown into plastic pots $(20 \times 20 \times 25 \mathrm{~cm}$; nine seeds per pot $)$, in six replicates (six pots) for each accession/treatment (control and inoculated plants) combination. The plants were cultivated in universal garden soil substrate $\mathrm{pH}=5.8$ (Ekoziem, Jurkow, Poland) mixed with sand $(1: 1, v / v)$. Before sowing, the seeds were sterilized in $70 \%$ ethanol for one minute and rinsed with sterile water three times for two minutes. Once a week, the plants were fertilized with Hoagland medium [83]. The plants were cultivated until the full anthesis stage $-65 \mathrm{BBCH}$ scale [40]. Their spikes were sprayed with the inoculum containing F. culmorum spores, while control spikes were sprayed with distilled water. Disease symptoms were evaluated seven and fourteen days after inoculation (DAI 7 and DAI 14). Ripe seeds were collected, and the following yield parameters were evaluated: Number and weight of seeds per spike, the weight of a single seed, and weight of one thousand seeds. Moreover, the content of the following mycotoxins was determined: deoxynivalenol (DON) and its derivatives 3-acetyldeoxynivalenol (3AcDON), 15-acetyldeoxynivalenol $(15 A c D O N)$, nivalenol (NIV), zearalenone (ZEN) and its derivatives alpha-Zearalanol $(\alpha-Z A L)$, beta-Zearalanol ( $\beta-Z A L)$, alpha-Zearalanol ( $\alpha-Z E L)$, beta-Zearalenol ( $\beta-Z E L)$, and $\mathrm{T}-2$ toxin.

\subsection{Analyses}

\subsubsection{Disease Rating (DR) and Loss of Fresh Weight (FW)}

Direct assessment based on disease rating (DR) was calculated with the formula described by Warzecha et al. [84] to determine the effect of infection on seedling and root development.

$$
\mathrm{DR} \%=100 \times\left(\mathrm{n}_{i} \times \mathrm{D}_{i}\right) / \mathrm{ND}_{\max }
$$

where: $\mathrm{n}_{i}$-number of plants of $i$ th category, $\mathrm{D}_{i}$-numerical value of $i$ th category, $\mathrm{N}$-total number of plants in the sample, and $D_{\max }$ - maximum scale value (0-5) [42]. 
To assess the impact of the infection, we also determined the fresh weight (FW) of leaves and roots. All measurements were done in thirty replicates for each cultivar/line.

\subsubsection{Chlorophyll $(\mathrm{a}, \mathrm{b})$ and Carotenoid (Car) Content}

Chlorophylls and carotenoids were estimated spectrophotometrically, according to Czyczyło-Mysza et al. [85]. Plant Leaves samples were dried at $65^{\circ} \mathrm{C}$ for $48 \mathrm{~h}$, weighed, and then extracted in $96 \%$ ethanol $\left(5 \mathrm{mg} / 1.5 \mathrm{~cm}^{3}\right)$, and centrifuged $(21,000 \times \mathrm{g}, 5 \mathrm{~min}$ at $15^{\circ} \mathrm{C}$ ). The extract was transferred to 96 well plate, and the absorbance was read at 470,648 , and $664 \mathrm{~nm}$ (Synergy II, Biotek, Winooski, VT, USA). The concentrations of Chla, Chlb, and total carotenoids (car) were calculated using Lichtenthaler and Buschman [86] equations:

$$
\begin{gathered}
\operatorname{Chl} a\left(\mu \mathrm{g} / \mathrm{cm}^{3}\right)=13.36 \mathrm{~A}_{664}-5.19 \mathrm{~A}_{648} \\
\operatorname{Chl} b\left(\mu \mathrm{g} / \mathrm{cm}^{3}\right)=27.43 \mathrm{~A}_{648}-8.12 \mathrm{~A}_{664} \\
\operatorname{Car}\left(\mu \mathrm{g} / \mathrm{cm}^{3}\right)=\left(1000 \mathrm{~A}_{470}-2.13 \mathrm{Chl} a-97.64 \mathrm{Chl} b\right) / 209
\end{gathered}
$$

where: Chl $a=$ chlorophyll $a$, Chl $b=$ chlorophyll $b, \mathrm{~A}_{470}=$ absorbance at $470 \mathrm{~nm}, \mathrm{~A}_{664}=$ absorbance at $664 \mathrm{~nm}, \mathrm{~A}_{648}=$ absorbance at $648 \mathrm{~nm}$.

\subsubsection{Determination of Total Water-Soluble Carbohydrates (TSC)}

Sugars were analyzed by the phenol-sulfuric method of Dubois et al. [87], with modifications reported by Bach et al. [88]. The samples extracted, as for pigment estimation $(10 \mu \mathrm{L})$ were diluted to $200 \mu \mathrm{L}$ with water, and $200 \mu \mathrm{L}$ of $5 \%$ phenol $(w / w)$ solution was added. Then, $1 \mathrm{~cm}^{3}$ of concentrated sulfuric acid was dispensed, the samples were mixed, and after $20 \mathrm{~min}$ incubation at ambient temperature and transferred to 96-well plates and absorbance was read at $490 \mathrm{~nm}$ (Synergy II, Biotek, Winooski, VT, USA). Sugar content was expressed as glucose equivalents-using the calibration curve obtained with a standard solution of glucose.

\subsubsection{Determination of Total Phenolic Compounds (TPC)}

Estimation of total phenolic content was done according to the Singleton method with modifications [88]. The extracts (prepared as described for pigments) were mixed with water diluted Folin-Ciocalteu phenol reagent $(5: 2, v / v)$ and after 10 min saturated $\mathrm{Na}_{2} \mathrm{CO}_{3}$ (c.a. $25 \% w / w)$ was added $(100 / 400 / 400 \mu \mathrm{L})$. The samples were then incubated for $2 \mathrm{~h}$ in darkness, at room temperature. After centrifugation $\left(21,000 \times g\right.$, for $15 \mathrm{~min}$ at $\left.15{ }^{\circ} \mathrm{C}\right)$, they were transferred to 96-well plates. Their absorbance was recorded at $760 \mathrm{~nm}$ (Synergy II, Biotek, Winooski, VT, USA). The pool of phenolic compounds was expressed as mg of gallic acid-using the calibration curve obtained with a standard solution of gallic acid.

\subsubsection{Determination of Cell Wall-Bound Phenolics (CWP)}

The pellets remaining after extraction of pigments were rinsed with ethanol and hydrolyzed with $3 \mathrm{M} \mathrm{NaOH}$ [89] overnight, at room temperature. Then the samples were neutralized with concentrated $\mathrm{HCl}$, then ethanol was added $\left(1 \mathrm{~cm}^{3}\right.$ per sample), and the resulting solution was analyzed for released phenolics as for soluble forms described in Section 4.2.4.

\subsubsection{Activity of Enzymatic Antioxidants}

Plant material was homogenized at $4{ }^{\circ} \mathrm{C}$ in $50 \mathrm{mM}$ (pH 7) phosphate-potassium buffer containing $0.1 \mathrm{mM}$ EDTA (100 mg of FW plant material per $1 \mathrm{~cm}^{3}$ of buffer). The activity of superoxide dismutase (SOD, EC 1.15.1.1), catalase (CAT, E.C. 1.11.1.6), and peroxidase (POX, EC 1.11.1.7) were determined. After centrifugation $\left(10,000 \times g, 15\right.$ min at $4{ }^{\circ} \mathrm{C}, 32 \mathrm{R}$, Hettich, Germany), clear supernatant was sub-sampled and assayed for SOD, CAT, and POX activity in 96-well plate format (Synergy II, Biotek, Winooski, VT). SOD activity was determined by the cytochrome reduction method of McCord and Fridovic [90]. CAT activity was measured at $240 \mathrm{~nm}$ according to Aebi [91], with $\mathrm{H}_{2} \mathrm{O}_{2}$ as a substrate. The 
activity of POX was assessed using the Lück [92] method with $p$-phenylenediamine as substrate, the absorbance was monitored at $485 \mathrm{~nm}$. The analyses were conducted as described by Gudys et al. and references are cited therein [93-95]. Enzyme activities were presented on a protein basis. Protein content was assayed with the standard Bradford method [96].

\subsubsection{Hydrogen Peroxide Content}

Plant material was homogenized at $4{ }^{\circ} \mathrm{C}$ in $50 \mathrm{mM}$ (pH 7) phosphate-potassium buffer containing $0.1 \mathrm{mM}$ EDTA, as described for enzyme activity analyses. Hydrogen peroxide content was estimated with a commercial Amplex Red (10-acetyl-3,7-dihydroxyphenoxa zine) [97] reagent kit (Invitrogen, Waltham, MA, USA), according to the manufacturer's manual [98]. Briefly, the plant sample was diluted with the reaction buffer, and the working solution containing fluorescence probe precursor (Amplex Red), and $0.2 \mathrm{U} \cdot \mathrm{cm}^{-3}$ horseradish peroxidase was added. After $30 \mathrm{~min}$ incubation, fluorescence was read at Ex/Em 530/590 nm in 96-well plate format (Synergy II, Biotek, Winooski, VT, USA). The results were quantitated based on a calibration curve made for $\mathrm{H}_{2} \mathrm{O}_{2}$.

\subsubsection{Spore Suspension Preparation and Spike Inoculation Procedure}

The spikes were inoculated with the spore suspension of F. culmorum prepared as described by Góral et al. [12]. The grain inoculated with F. culmorum mycelium and conidia were soaked in distilled water for $1 \mathrm{~h}$ and then filtered over two layers of sterile cheesecloth. The spore concentration of the suspension was adjusted to $5 \times 10^{5}$ spores $\cdot \mathrm{cm}^{-3}$ using Thoma's chamber. The inoculation was performed according to the methodology described by Warzecha et al. [99], with slight modifications. The spikes from each line were sprayed separately with a hand sprayer, using $2 \mathrm{~cm}^{3}$ of the conidia suspension per spike, and covered for $48 \mathrm{~h}$ with plastic bags. Control plants were sprayed with distilled water, and covered with plastics bags to provide the same experimental conditions. Inoculation was done early in the morning, when the air humidity was relatively high $(70-80 \%)$ and the temperature was low $\left(10-14{ }^{\circ} \mathrm{C}\right)$.

The spike inoculation procedure was performed twice. The first inoculation was done three days before the full anthesis stage and repeated seven days later. Seven days after each inoculation, Fusarium head blight index (FHBi) was visually evaluated for each accession and calculated using the formula described by Góral et al. [12]:

$$
\mathrm{FHBi}=\% \text { of head infection } \times \% \text { of head infection per accession } / 100
$$

Forty-five spikes from each accession at the full ripening stage were harvested, evaluated for yield reduction after Fusarium inoculation, and compared with non-inoculated plants. The following yield parameters were calculated: Amount of grain per spike, grain mass per spike, mass of a single grain, and mass of one thousand grains (MTS). After the evaluation of the yield parameters, seed material was collected and stored at $-20^{\circ} \mathrm{C}$ until mycotoxin analyzes.

\subsubsection{UHPLC-MS/MS Estimation of Mycotoxin Accumulation}

The samples were analyzed for the content of 10 different mycotoxins by using UHPLC-MS/MS (ultrahigh-performance liquid chromatography coupled with tandem mass spectrometer) as reported by Dziurka et al. [100], with modifications. Plant materials were extracted according to the procedure described by Klötzel and Lauber [101]. The ground samples $(0.1 \mathrm{~g})$ were extracted three times in $1 \mathrm{~cm}^{3}$ of acetonitrile and water $(80: 20$, $v / v$ ) solution ( $5 \mathrm{~min}, 30 \mathrm{~Hz}, 400 \mathrm{MM}$, Retch, Haan, Germany). Fifty nanograms of heavylabeled internal standard $\left(\left[{ }^{13} \mathrm{C}_{18}\right]-\mathrm{ZEN}\right.$, and $\left.\left[{ }^{13} \mathrm{C}_{15}\right]-\mathrm{DON}\right)$ were added to each sample. After centrifugation, the samples were cleaned up on Bond Elut Mycotoxin cartridges $\left(3 \mathrm{~cm}^{3} 500 \mathrm{mg}\right.$, Agilent Technologies, Germany). The column eluate was evaporated under $\mathrm{N}_{2}$, and the residue was resuspended in $100 \mu \mathrm{L}$ of acetonitrile/water $(50: 50, v / v)$, and analyzed. The mycotoxins (DON, NIV, sum of 3-acetyl-DON and 15-acetyl-DON, T-2, 
sum of zearalenone and its derivatives: a-, b-ZEL, a-, b-ZAN and ZEN, and OTA) were determined using the UHPLC system (Infinity 1260, Agilent Technologies, Germany) with a tandem quadrupole mass spectrometer (QQQ 6410, Agilent Technologies, USA). The samples were separated on a Poroshell 120 Phenyl-Hexyl $2.1 \times 5 \mathrm{~mm}, 2.7 \mu \mathrm{M}$ column with a gradient of water (A) and methanol (B) both with $0.1 \%$ formic acid, from $5 \%$ to $75 \%$ methanol in $7.5 \mathrm{~min}$, at a flow rate of $0.5 \mathrm{~cm}^{3} \mathrm{~min}^{-1}$. Multiple reaction monitoring (MRM) transitions after positive ESI ionization were used for identification and quantification (details are given in Table S1). Quantitation was based on calibration curves obtained with authentic standards taking account of the recovery rates of the internal standard used. The standards were supplied by Romer (Tulin, Austria), except for zearalenone and its derivatives which were supplied by Sigma-Aldrich (Poznań, Poland)

\subsubsection{Yield Components}

Ripe seeds were collected, and the yield parameters were evaluated. Number and weight of seeds per spike were calculated in 45 replicates, the weight of a single seed was measured in 45 replicates, while the mass of one thousand seeds (MTS) was measured in three replicates, for each accession/treatment combination.

\subsection{Statistical Analyses}

The experiments were arranged and performed with the application of a completely randomized design. The normal distribution of data was analyzed using Shapiro-Wilk test. Two-way analysis of variance (ANOVA) and Duncan's multiple range test (at $p<0.05)$ were performed using the statistical package Statistica 13.3 (Stat-Soft, Inc., Tulsa, OK, USA). The data were presented as means \pm SE (standard error). Pearson's correlation coefficients were assumed as statistically significant at $p<0.05$.

\section{Conclusions}

1. Fusarium culmorum infection significantly reduces the content of active photosynthetic pigments and the weight of leaves and roots.

2. The infected $\mathrm{cv}$. 'Tamaroi' and $\mathrm{BC}_{5} \mathrm{Nax}_{2}$ plants recognized as more resistant to F. culmorum than SMH87, accumulated increased amounts of sugar in the leaves, which correlated with an increased number of phenolic compounds.

3. Phenolic compounds participate in $\mathrm{H}_{2} \mathrm{O}_{2}$ decomposition in durum wheat plants infected by F. culmorum.

4. The study confirmed the important role of $\mathrm{H}_{2} \mathrm{O}_{2}$ in increasing the content of phenolic compounds that are then incorporated into cell walls of plants infected with F. culmorum.

5. Nivalenol and deoxynivalenol secreted by F. cumlorum significantly reduce the yield of durum wheat.

6. Early evaluation of durum wheat spikes infection done seven days after inoculation with F. culmorum spores may help predict the potential degree of DON and NIV accumulation in the grain.

Supplementary Materials: The following are available online at https:/ / www.mdpi.com/article/10 $.3390 /$ ijms22147433/s1, Table S1: Multiple reactions monitoring (MRM) transitions for the analyzed mycotoxins at positive ion mode (+ESI), capillary voltage $4 \mathrm{kV}$, gas temperature $300{ }^{\circ} \mathrm{C}$, gas flow $12 \mathrm{~L} / \mathrm{min}$ and nebulizer pressure $35 \mathrm{psi}$. MassHunter software was used to control the UHPLCMS/MS system and in data analysis. For MRM parameters optimization MassHunter Optimizer was used.

Author Contributions: The experiments were conceived and designed by J.P. and A.P.; the experiments were performed by J.P.; biochemical analyses were performed by J.P., A.S., M.D., M.H., P.K. and M.S.; UHPLC-MS/MS analyses was performed by M.D.; the data were statistically analyzed by J.P., A.P.; the original draft paper was written by J.P.; the review and editing were done by J.P. and A.P. All authors have read and agreed to the published version of the manuscript. 
Funding: This research was supported by the Polish Ministry of Education and Science (scientific subsidy for the University of Agriculture in Kraków).

Institutional Review Board Statement: Not applicable.

Informed Consent Statement: Not applicable.

Data Availability Statement: All data relevant to the main findings of this study are included within the article and supplementary material.

Conflicts of Interest: The authors declare no conflict of interest.

\section{References}

1. Xu, X.; Nicholson, P. Community Ecology of Fungal Pathogens Causing Wheat Head Blight. Annu. Rev. Phytopathol. 2009, 47, 83-103. [CrossRef]

2. Salgado, J.D.; Madden, L.; Paul, P.A. Efficacy and Economics of Integrating In-Field and Harvesting Strategies to Manage Fusarium Head Blight of Wheat. Plant Dis. 2014, 98, 1407-1421. [CrossRef] [PubMed]

3. Wang, H.; Sun, S.; Ge, W.; Zhao, L.; Hou, B.; Wang, K.; Lyu, Z.; Chen, L.; Xu, S.; Guo, J.; et al. Horizontal gene transfer of Fhb7 from fungus underlies Fusarium head blight resistance in wheat. Science 2020, 368, eaba5435. [CrossRef] [PubMed]

4. Bennett, J.W.; Klich, M. Mycotoxins. Clin. Microbiol. Rev. 2003, 16, 497-516. [CrossRef]

5. Trail, F. For Blighted Waves of Grain: Fusarium graminearum in the Postgenomics Era. Plant Physiol. 2009, 149, 103-110. [CrossRef] [PubMed]

6. Bottalico, A.; Perrone, G. Toxigenic Fusarium species and mycotoxins associated with head blight in small-grain cereals in Europe. Mycotoxins Plant Dis. 2002, 108, 611-624. [CrossRef]

7. Foroud, N.A.; Eudes, F. Trichothecenes in Cereal Grains. Int. J. Mol. Sci. 2009, 10, 147-173. [CrossRef]

8. Marín, S.; Ramos, A.J.; Cano-Sancho, G.; Sanchis, V. Mycotoxins: Occurrence, toxicology, and exposure assessment. Food Chem. Toxicol. 2013, 60, 218-237. [CrossRef]

9. Commission Regulation (EC) No 1126/2007 of 28 September 2007 Amending Regulation (EC) No 1881/2006 Setting Maximum Levels for Certain Contaminants in Foodstuffs as Regards Fusarium Toxins in Maize and Maize Products (Text with EEA Relevance). Available online: https:/ / eur-lex.europa.eu/legal-content/EN/ALL/?uri=CELEX:32007R1126 (accessed on 2 February 2021).

10. Commission Recommendation of 17 August 2006 on the Presence of Deoxynivalenol, Zearalenone, Ochratoxin A, T-2 and HT-2 and Fumonisins in Products Intended for Animal Feeding (Text with EEA Relevance). Available online: https:/ / eur-lex.europa. eu/legal-content/EN/TXT/?uri=CELEX:32006H0576 (accessed on 2 February 2021).

11. Boutigny, A.-L.; Richard-Forget, F.; Barreau, C. Natural mechanisms for cereal resistance to the accumulation of Fusarium trichothecenes. Eur. J. Plant Pathol. 2008, 121, 411-423. [CrossRef]

12. Góral, T.; Wiśniewska, H.; Ochodzki, P.; Nielsen, L.K.; Walentyn-Góral, D.; Stẹpień, Ł. Relationship between Fusarium Head Blight, Kernel Damage, Concentration of Fusarium Biomass, and Fusarium Toxins in Grain of Winter Wheat Inoculated with Fusarium culmorum. Toxins 2018, 11, 2. [CrossRef]

13. Tarkowski, Ł.P.; Van De Poel, B.; Höfte, M.; Ende, W.V.D. Sweet Immunity: Inulin Boosts Resistance of Lettuce (Lactuca sativa) against Grey Mold (Botrytis cinerea) in an Ethylene-Dependent Manner. Int. J. Mol. Sci. 2019, 20, 1052. [CrossRef]

14. Streuter, N.; Moerschbacher, B.; Fischer, Y.; Noll, U.; Reisener, H. Fructose-2,6-Bisphosphate in Wheat Leaves Infected with Stem Rust. J. Plant Physiol. 1989, 134, 254-257. [CrossRef]

15. Gaudet, D.A.; Laroche, A.; Yoshida, M. Low temperature-wheat-fungal interactions: A carbohydrate connection. Physiol. Plant. 1999, 106, 437-444. [CrossRef]

16. Morkunas, I.; Marczak, Ł.; Stachowiak, J.; Stobiecki, M. Sucrose-induced lupine defense against Fusarium oxysporum: Sucrosestimulated accumulation of isoflavonoids as a defense response of lupine to Fusarium oxysporum. Plant Physiol. Biochem. 2005, 43, 363-373. [CrossRef]

17. Nicholson, R.L.; Hammerschmidt, R. Phenolic Compounds and Their Role in Disease Resistance. Annu. Rev. Phytopathol. 1992, 30, 369-389. [CrossRef]

18. Zaynab, M.; Fatima, M.; Abbas, S.; Sharif, Y.; Umair, M.; Zafar, M.H.; Bahadar, K. Role of secondary metabolites in plant defense against pathogens. Microb. Pathog. 2018, 124, 198-202. [CrossRef] [PubMed]

19. Walter, S.; Nicholson, P.; Doohan, F. Action and reaction of host and pathogen during Fusarium head blight disease. New Phytol. 2009, 185, 54-66. [CrossRef] [PubMed]

20. Das, K.; Roychoudhury, A. Reactive oxygen species (ROS) and response of antioxidants as ROS-scavengers during environmental stress in plants. Front. Environ. Sci. 2014, 2, 53. [CrossRef]

21. De Gara, L.; Locato, V.; Dipierro, S.; de Pinto, M.C. Redox homeostasis in plants. The challenge of living with endogenous oxygen production. Respir. Physiol. Neurobiol. 2010, 173, S13-S19. [CrossRef]

22. Foyer, C.H.; Noctor, G. Redox homeostasis and antioxidant signaling: A metabolic interface between stress perception and physiological responses. Plant Cell 2005, 17, 1866-1875. [CrossRef] 
23. Zurbriggen, M.D.; Carrillo, N.; Tognetti, V.B.; Melzer, M.; Peisker, M.; Hause, B.; Hajirezaei, M.-R. Chloroplast-generated reactive oxygen species play a major role in localized cell death during the non-host interaction between tobacco and Xanthomonas campestris pv. vesicatoria. Plant J. 2009, 60, 962-973. [CrossRef] [PubMed]

24. Barna, B.; Fodor, J.; Harrach, B.; Pogany, M.; Király, Z. The Janus face of reactive oxygen species in resistance and susceptibility of plants to necrotrophic and biotrophic pathogens. Plant Physiol. Biochem. 2012, 59, 37-43. [CrossRef]

25. Waśkiewicz, A.; Beszterda, M.; Goliński, P. Nonenzymatic Antioxidants in Plants. In Oxidative Damage to Plants; Elsevier: Amsterdam, The Netherlands, 2014; pp. 201-234.

26. Yang, T.; Poovaiah, B.W. Hydrogen peroxide homeostasis: Activation of plant catalase by calcium/calmodulin. Proc. Natl. Acad. Sci. USA 2002, 99, 4097-4102. [CrossRef] [PubMed]

27. Madadkhah, E.; Lotfi, M.; Nabipour, A.; Rahmanpour, S.; Banihashemi, Z.; Shoorooei, M. Enzymatic activities in roots of melon genotypes infected with Fusarium oxysporum f. sp. melonis race 1. Sci. Hortic. 2012, 135, 171-176. [CrossRef]

28. Wang, W.; Xia, M.X.; Chen, J.; Yuan, R.; Deng, F.N.; Shen, F. Gene expression characteristics and regulation mechanisms of superoxide dismutase and its physiological roles in plants under stress. Biochemistry 2016, 81, 465-480. [CrossRef]

29. Gechev, T.S.; Hille, J. Hydrogen peroxide as a signal controlling plant programmed cell death. J. Cell Biol. 2005, 168, 17-20. [CrossRef] [PubMed]

30. Hao, S.; Liu, S.; Zhang, Z.; Gui, H.; Duan, J.; Chen, Q. Characteristics of chlorophyll metabolism and chlorophyll fluorescence in the silvered leaf of summer squash. Acta Hortic. Sinica. 2009, 36, 879-884.

31. Alwathnani, H.A. Biological control of fusarium wilt of tomato by antagonist fungi and cyanobacteria. Afr. J. Biotechnol. 2012, 11, 1100-1105. [CrossRef]

32. Warzecha, T.; Skrzypek, E.; Sutkowska, A. Effect of Fusarium culmorum infection on selected physiological and biochemical parameters of barley (Hordeum vulgare L.) DH lines. Physiol. Mol. Plant Pathol. 2015, 89, 62-69. [CrossRef]

33. Wagacha, J.; Muthomi, J. Fusarium culmorum: Infection process, mechanisms of mycotoxin production and their role in pathogenesis in wheat. Crop. Prot. 2007, 26, 877-885. [CrossRef]

34. Chekali, S.; Gargouri, S.; Paulitz, T.; Nicol, J.M.; Rezgui, M.; Nasraoui, B. Effects of Fusarium culmorum and water stress on durum wheat in Tunisia. Crop. Prot. 2011, 30, 718-725. [CrossRef]

35. James, R.A.; Blake, C.; Zwart, A.B.; Hare, R.A.; Rathjen, A.J.; Munns, R. Impact of ancestral wheat sodium exclusion genes Nax1 and Nax2 on grain yield of durum wheat on saline soils. Funct. Plant Biol. 2012, 39, 609-618. [CrossRef] [PubMed]

36. Pastuszak, J.; Kopeć, P.; Płażek, A.; Gondek, K.; Szczerba, A.; Hornyák, M.; Dubert, F. Cadmium accumulation in the grain of durum wheat is associated with salinity resistance degree. Plant Soil Environ. 2020, 66, 257-263. [CrossRef]

37. Pastuszak, J.; Kopeć, P.; Płażek, A.; Gondek, K.; Szczerba, A.; Hornyák, M.; Dubert, F. Antioxidant activity as a response to cadmium pollution in three durum wheat genotypes differing in salt-tolerance. Open Chem. 2020, 18, 1230-1241. [CrossRef]

38. Lops, R.; Pascale, M.; Pancaldi, D.; Visconti, A. Infezionifungine e presenza di deossinivalenolo in cariossidi di frumento-prodotte in diverse regioniitaliane. Inf. Fitopatol. 1998, 48, 60-66.

39. Miedaner, T.; Longin, C.F.H. Genetic variation for resistance to Fusarium head blight in winter durum material. Crop. Pasture Sci. 2014, 65, 46-51. [CrossRef]

40. Lancashire, P.D.; Bleiholder, H.; Van Den Boom, T.; Langelüddeke, P.; Stauss, R.; Weber, E.; Witzenberger, A. A uniform decimal code for growth stages of crops and weeds. Ann. Appl. Biol. 1991, 119, 561-601. [CrossRef]

41. Grey, W.E.; Mathre, D.E. Evaluation of spring barleys for reaction to Fusarium culmorum seedling blight and root rot. Can. J. Plant Sci. 1988, 68, 23-30. [CrossRef]

42. Wojciechowski, S.; Chelkowski, J.; Ponitka, A.; Ślusarkiewicz-Jarzina, A. Evaluation of Spring and Winter Wheat Reaction to Fusarium culmorum and Fusarium avenaceum. J. Phytopathol. 1997, 145, 99-103. [CrossRef]

43. Warzecha, T.; Zieliński, A.; Skrzypek, E.; Wójtowicz, T.; Moś, M. Effect of mechanical damage on vigor, physiological parameters, and susceptibility of oat (Avena sativa) to Fusarium culmorum infection. Phytoparasitica 2012, 40, 29-36. [CrossRef]

44. Malalasekera, R.; Sanderson, F.; Colhoun, J. Fusarium diseases of cereals: IX. Penetration and invasion of wheat seedlings by Fusarium culmorum and F. nivale. Trans. Br. Mycol. Soc. 1973, 60, 453-462.IN7. [CrossRef]

45. Knudsen, I.M.B.; Hockenhull, J.; Jensen, D. Biocontrol of seedling diseases of barley and wheat caused by Fusarium culmorum and Bipolaris sorokiniana: effects of selected fungal antagonists on growth and yield components. Plant Pathol. 1995, 44, 467-477. [CrossRef]

46. Płażek, A. Relationship between soluble carbohydrate level and tolerance of meadow fescue callus to Bipolaris sorokiniana (Sacc.) Shoem. and Drechslera dictyoides (Drechsl.) Shoem. metabolites. Acta Physiol. Plant. 1998, 20, 347-351. [CrossRef]

47. Herbers, K.; Takahata, Y.; Melzer, M.; Mock, H.-P.; Hajirezaei, M.; Sonnewald, U. Regulation of carbohydrate partitioning during the interaction of potato virus Y with tobacco. Mol. Plant Pathol. 2000, 1, 51-59. [CrossRef] [PubMed]

48. Pociecha, E.; Płażek, A.; Janowiak, F.; Dubert, F.; Kolasińska, I.; Irla, M. Factors contributing to enhanced pink snow mould resistance of winter rye (Secale cereale L.)-Pivotal role of crowns. Physiol. Mol. Plant Pathol. 2013, 81, 54-63. [CrossRef]

49. Eveland, A.; Jackson, D.P. Sugars, signalling, and plant development. J. Exp. Bot. 2012, 63, 3367-3377. [CrossRef] [PubMed]

50. Bani, M.; Pérez-De-Luque, A.; Rubiales, D.; Rispail, N. Physical and Chemical Barriers in Root Tissues Contribute to Quantitative Resistance to Fusarium oxysporum f. sp. pisi in Pea. Front. Plant Sci. 2018, 9, 199. [CrossRef] [PubMed] 
51. Formela-Luboińska, M.; Remlein-Starosta, D.; Waśkiewicz, A.; Karolewski, Z.; Bocianowski, J.; Stępień, Ł.; Labudda, M.; Jeandet, P.; Morkunas, I. The Role of Saccharides in the Mechanisms of Pathogenicity of Fusarium oxysporum f. sp. lupini in Yellow Lupine (Lupinus luteus L.). Int. J. Mol. Sci. 2020, 21, 7258. [CrossRef]

52. Goodman, R.N.; Király, Z.; Wood, K.R. The Biochemistry and Physiology of Plant Disease; University of Missouri Press: Columbia, MO, USA, 1986.

53. Płażek, A.; Hura, K.; Żur, I. Reaction of winter oilseed rape callus to different concentrations of elicitors: Pectinase or chitosan. Acta Physiol. Plant. 2003, 25, 83-89. [CrossRef]

54. Płażek, A.; Hura, K.; Żur, I. Influence of chitosan, pectinase and fungal metabolites on activation of phenylopropanoid pathway and antioxidant activity in oilseed rape callus. Acta Physiol. Plant. 2005, 27, 95-102.

55. Hura, K.; Hura, T.; Dziurka, K.; Dziurka, M. Biochemical defense mechanisms induced in winter oilseed rape seedlings with different susceptibility to infection with Leptosphaeria maculans. Physiol. Mol. Plant Pathol. 2014, 87, 42-50. [CrossRef]

56. Derckel, J.-P.; Audran, J.-C.; Haye, B.; Lambert, B.; Legendre, L. Characterization, induction by wounding and salicylic acid, and activity against Botrytis cinerea of chitinases and $\beta-1,3$-glucanases of ripening grape berries. Physiol. Plant. 1998, 104, 56-64. [CrossRef]

57. Arora, N.K.; Kim, M.J.; Kang, S.C.; Maheshwari, D.K. Role of chitinase and $\beta$-1,3-glucanase activities produced by a fluorescent pseudomonad and in vitro inhibition of Phytophthora capsici and Rhizoctonia solani. Can. J. Microbiol. 2007, 53, 207-212. [CrossRef] [PubMed]

58. Smith, C. Tansley Review No. 86 Accumulation of phytoalexins: Defence mechanism and stimulus response system. New Phytol. 1996, 132, 1-45. [CrossRef]

59. Bizuneh, G.K. The chemical diversity and biological activities of phytoalexins. Adv. Tradit. Med. 2021, 21, 31-43. [CrossRef]

60. Hakulinen, J.; Sorjonen, S.; Julkunen-Tiitto, R. Leaf phenolics of three willow clones differing in resistance to Melampsora rust infection. Physiol. Plant. 1999, 105, 662-669. [CrossRef]

61. Dixon, R.A.; Paiva, N.L. Stress-Induced Phenylpropanoid Metabolism. Plant Cell 1995, 7, 1085-1097. [CrossRef] [PubMed]

62. Jackson, A.O.; Taylor, C.B. Plant-Microbe Interactions: Life and Death at the Interface. Plant Cell 1996, 8, 1651-1668. [CrossRef]

63. Datta, J.; Lal, N. Temporal and spatial changes in phenolic compounds in response to Fusarium wilt in chickpea and pigeon pea. Cell. Mol. Boil. 2012, 58, 96-102.

64. Noman, A.; Aqeel, M.; Qari, S.H.; Al Surhanee, A.A.; Yasin, G.; Alamri, S.; Hashem, M.; Al-Saadi, A.M. Plant hypersensitive response vs pathogen ingression: Death of few gives life to others. Microb. Pathog. 2020, 145, 104224. [CrossRef]

65. Badawi, G.H.; Yamauchi, Y.; Shimada, E.; Sasaki, R.; Kawano, N.; Tanaka, K.; Tanaka, K. Enhanced tolerance to salt stress and water deficit by overexpressing superoxide dismutase in tobacco (Nicotiana tabacum) chloroplasts. Plant Sci. 2004, 166, 919-928. [CrossRef]

66. Xu, J.; Duan, X.; Yang, J.; Beeching, J.R.; Zhang, P. Enhanced Reactive Oxygen Species Scavenging by Overproduction of Superoxide Dismutase and Catalase Delays Postharvest Physiological Deterioration of Cassava Storage Roots. Plant Physiol. 2013, 161, 1517-1528. [CrossRef]

67. Helepciuc, F.E.; Mitoi, M.E.; Manole-Paunescu, A.; Aldea, F.; Brezeanu, A.; Cornea, C.P. Induction of plant antioxidant system by interaction with beneficial and/or pathogenic microorganisms. Rom. Biotech. Lett. 2014, 19, 9366-9375.

68. Torres, M.A.; Jones, J.; Dangl, J.L. Reactive Oxygen Species Signaling in Response to Pathogens. Plant Physiol. 2006, 141, 373-378. [CrossRef]

69. Morkunas, I.; Gmerek, J. The possible involvement of peroxidase in defense of yellow lupine embryo axes against Fusarium oxysporum. J. Plant Physiol. 2007, 164, 185-194. [CrossRef]

70. Mandal, S.; Mitra, A.; Mallick, N. Biochemical characterization of oxidative burst during interaction between Solanum lycopersicum and Fusarium oxysporum f. sp. lycopersici. Physiol. Mol. Plant Pathol. 2008, 72, 56-61. [CrossRef]

71. Plazek, A.; Zur, I. Cold-induced plant resistance to necrotrophic pathogens and antioxidant enzyme activities and cell membrane permeability. Plant Sci. 2003, 164, 1019-1028. [CrossRef]

72. Bushnell, W.R.; Hazen, E.; Pritsch, C. Histology and physiology of Fusarium head blight. In Fusarium Head Blight of Wheat and Barley; Leonard, K.J., Bushnell, W.R., Eds.; American Phytopathological Society: St. Paul, MN, USA, 2003; pp. 44-83.

73. Gale, L.R.; Harrison, S.A.; Ward, T.J.; O’Donnell, K.; Milus, E.A.; Gale, S.W.; Kistler, H. Nivalenol-Type Populations of Fusarium graminearum and F. asiaticum Are Prevalent on Wheat in Southern Louisiana. Phytopatholigy 2011, 101, 124-134. [CrossRef] [PubMed]

74. Haidukowski, M.; Pascale, M.; Perrone, G.; Pancaldi, D.; Campagna, C.; Visconti, A. Effect of fungicides on the development of Fusarium head blight, yield and deoxynivalenol accumulation in wheat inoculated under field conditions with Fusarium graminearum and Fusarium culmorum. J. Sci. Food Agric. 2004, 85, 191-198. [CrossRef]

75. Nowicki, T. Vomitoxin And Fusarium Damaged Kernels-Is There A Relationship in Canadian Wheat? In Proceedings of the 2nd Canadian Workshop on Fusarium Head Blight, Ottawa, ON, Canada, 3-5 November 2001.

76. Pascale, M.; Visconti, A.; Chelkowski, J. Ear Rot Susceptibility and Mycotoxin Contamination of Maize Hybrids Inoculated with Fusarium Species Under Field Conditions. Eur. J. Plant Pathol. 2002, 108, 645-651. [CrossRef]

77. Goswami, R.S.; Kistler, H. Pathogenicity and In Planta Mycotoxin Accumulation Among Members of the Fusarium graminearum Species Complex on Wheat and Rice. Phytopathology 2005, 95, 1397-1404. [CrossRef] 
78. Liu, Y.-Y.; Sun, H.-Y.; Li, W.; Xia, Y.-L.; Deng, Y.-Y.; Zhang, A.-X.; Chen, H.-G. Fitness of three chemotypes of Fusarium graminearum species complex in major winter wheat-producing areas of China. PLoS ONE 2017, 12, e0174040. [CrossRef]

79. Desjardins, A.E.; Plattner, R.D. Diverse traits for pathogen fitness inGibberella zeae. Can. J. Plant Pathol. 2003, 25, 21-27. [CrossRef]

80. Llorens, A.; Mateo, R.; Hinojo, M.; Valle-Algarra, F.; Jiménez, M. Influence of environmental factors on the biosynthesis of type B trichothecenes by isolates of Fusarium spp. from Spanish crops. Int. J. Food Microbiol. 2004, 94, 43-54. [CrossRef]

81. Wiśniewska, H.; Góral, T.; Ochodzki, P.; Walentyn-Góral, D.; Kwiatek, M.; Majka, M.; Kurleto, D. Resistance of winter triticale breeding lines to Fusarium head blight. Bull. Plant Breed. Acclim. Inst. 2014, 271, 29-43.

82. Murashige, T.; Skoog, F. A Revised Medium for Rapid Growth and Bio Assays with Tobacco Tissue Cultures. Physiol. Plant. 1962, 15, 473-497. [CrossRef]

83. Hoagland, D.R.; Arnon, D.I. The water-culture method for growing plants without soil. Univ. Calif. Agric. Exp. Stn. Circ. 1938, $347,29-32$.

84. Warzecha, T.; Skrzypek, E.; Adamski, T.; Surma, M.; Kaczmarek, Z.; Sutkowska, A. Chlorophyll a Fluorescence Parameters of Hulled and Hull-less Barley (Hordeum vulgare L.) DH Lines Inoculated with Fusarium culmorum. Plant Pathol. J. 2019, 35, 112-124. [CrossRef] [PubMed]

85. Czyczyło-Mysza, I.; Tyrka, M.; Marcińska, I.; Skrzypek, E.; Karbarz, M.; Dziurka, M.; Hura, T.; Quarrie, S. Quantitative trait loci for leaf chlorophyll fluorescence parameters, chlorophyll and carotenoid contents in relation to biomass and yield in bread wheat and their chromosome deletion bin assignments. Mol. Breed. 2013, 32, 189-210. [CrossRef]

86. Lichtenthaler, H.K.; Buschmann, C. Chlorophylls and Carotenoids: Measurement and Characterization by UV-VIS Spectroscopy. Curr. Protoc. Food Anal. Chem. 2001, 1, F4-3. [CrossRef]

87. Dubois, M.Y.; A Gilles, K.; Hamilton, J.K.; Rebers, P.A.; Smith, F.G. A Colorimetric Method for the Determination of Sugars. Nat. Cell Biol. 1951, 168, 167. [CrossRef]

88. Bach, A.; Kapczyńska, A.; Dziurka, M. Phenolic compounds and carbohydrates in relation to bulb formation in Lachenalia 'Ronina' and 'Rupert' in vitro cultures under different lighting environments. Sci. Hortic. 2015, 188, 23-29. [CrossRef]

89. Hura, T.; Dziurka, M.; Hura, K.; Ostrowska, A.; Dziurka, K. Different allocation of carbohydrates and phenolics in dehydrated leaves of triticale. J. Plant Physiol. 2016, 202, 1-9. [CrossRef]

90. Mccord, J.M.; Fridovich, I. Superoxide dismutase. An enzymic function for erythrocuprein (hemocuprein). J. Biol. Chem. 1969, 244, 6049-6055. [CrossRef]

91. Aebi, H. Catalase in vitro. Methods Enzymol. 1984, 105, 121-126. [CrossRef] [PubMed]

92. Luck, H. Methoden der enzymatischenanalyse. In Verlag Chemie, 1st ed.; Bergmeyer, H.U.: Weinheim, Germany, 1962.

93. Gudyś, K.; Guzy-Wrobelska, J.; Janiak, A.; Dziurka, M.A.; Ostrowska, A.; Hura, K.; Jurczyk, B.; Żmuda, K.; Grzybkowska, D.; Śróbka, J.; et al. Prioritization of Candidate Genes in QTL Regions for Physiological and Biochemical Traits Underlying Drought Response in Barley (Hordeum vulgare L.). Front. Plant Sci. 2018, 9, 1-26. [CrossRef]

94. Szechynska-Hebda, M.; Skrzypek, E.; Dąbrowska, G.; Wędzony, M.; Van Lammeren, A. The effect of endogenous hydrogen peroxide induced by cold treatment in the improvement of tissue regeneration efficiency. Acta Physiol. Plant. 2011, 34, 547-560. [CrossRef]

95. Wojtania, A.; Skrzypek, E.; Gabryszewska, E. Morphological and Biochemical Responses to Gibberellic Acid in Magnolia $\times$ 'Spectrum' in Vitro. Acta Biol. Cracoviensias. Bot. 2016, 58, 103-111. [CrossRef]

96. Bradford, M.M. A rapid and sensitive method for the quantitation of microgram quantities of protein utilizing the principle of protein-dye binding. Anal. Biochem. 1976, 72, 248-254. [CrossRef]

97. Mohanty, J.; Jaffe, J.S.; Schulman, E.S.; Raible, D.G. A highly sensitive fluorescent micro-assay of $\mathrm{H}_{2} \mathrm{O}_{2}$ release from activated human leukocytes using a dihydroxyphenoxazine derivative. J. Immunol. Methods 1997, 202, 133-141. [CrossRef]

98. ThermoFisher Protocol of Amplex®Red Hydrogen Peroxide/Peroxidase Assay Kit. Available online: https://www.thermofisher. com/document-connect/document-connect.html?url=https://assets.thermofisher.com/TFS-Assets/LSG/manuals/mp22188 .pdf (accessed on 30 June 2021).

99. Warzecha, T.; Adamski, T.; Kaczmarek, Z.; Surma, M.; Goliński, P.; Perkowski, J.; Chełkowski, J.; Wiśniewska, H.; Krystkowiak, K.; Kuczynska, A. Susceptibility of hulled and hulless barley doubled haploids to Fusarium culmorum head blight. Cereal Res. Commun. 2010, 38, 220-232. [CrossRef]

100. Dziurka, M.; Maksymowicz, A.; Ostrowska, A.; Biesaga-Kościelniak, J. The Interaction Effect of Drought and Exogenous Application of Zearalenone on the Physiological, Biochemical Parameters and Yield of Legumes. J. Plant Growth Regul. 2020, 2020, 1-12. [CrossRef]

101. Klötzel, M.; Lauber, U.; Humpf, H.-U. A new solid phase extraction clean-up method for the determination of 12 type A and B trichothecenes in cereals and cereal-based food by LC-MS/MS. Mol. Nutr. Food Res. 2006, 50, 261-269. [CrossRef] [PubMed] 